\title{
El joven envejecido. Arte en Chile de 1988 a 1968
}

\author{
The aged young man. Art in Chile, from 1988 to 1968
}

Carolina Olmedo Carrasco*

\begin{abstract}
Resumen:
En debate con los postulados instalados por el pensamiento postmodernista y de la renovación socialista durante los ochenta, y en diálogo con los "largos sesenta" latinoamericanos como perspectiva, se plantea una mirada amplia sobre el escenario artístico chileno desde 1965 y hasta el periodo de la Unidad Popular, constatando en las fuentes la diversidad temática, estética e ideológica que atravesaba la producción artística de la esfera militante. A partir de esto, el ensayo se detiene en dos ejes de articulación: el auge de las militancias políticas en el campo artístico y la emergencia de un "universo juvenil" que busca fundir vida, arte y vanguardia en un nuevo realismo y un $p \circ p$ art nacional que encara en clave propia la masificación de la cultura.
\end{abstract}

Palabras clave: Arte político, arte chileno, militancia, sesentas, intelectuales en el arte

\section{Abstract:}

In confrontation with the ideas installed by postmodernist intellectuals in the chilean socialism renovation during the eighties, and in dialogue with the Latin American "long sixties" perspective, we offer a broad view of the Chilean artistic scene from 1965 until the period of the Popular Unity government, observing in the sources a diversity of thematics, aesthetics and ideological points of view that crossed the artistic production in the political organizations sphere. Our essay stops in the rise of political militancy in the artistic field and the emergence of a "youth universe" that seeks to fuse life, art and vanguard in a new realism and a national pop art that confronted in own terms the massification of the local culture.

Keywords: Political art, chilean art, militancy, sixties, intellectuals in art

*Carolina Olmedo Carrasco (Santiago de Chile, 1984), investigadora en arte contemporáneo, Licenciada en Arte UC, Doctora (c) en Estudios Latinoamericanos por la Universidad de Chile. Docente del Instituto de Música de la Universidad Alberto Hurtado y del Instituto de Estudios Humanísticos Abate Molina, Universidad de Talca. carolinaolmedocarrasco@gmail.com 
Salvo contados trabajos, la relación entre arte y política es uno de los temas que más páginas sobre historia y teoría del arte se ha producido en el contexto de la escena artística chilena de los últimos cuarenta años. A través de ciertos trabajos recientes de investigación sobre las décadas del setenta a los dos mil en nuestro país ${ }^{1}$, sabemos que esta relación fue dinámica y protagónica en momentos en que estuvo aparejada a una amplia movilización social que demandaba insumos y discursos para extender su expresión a cualquier rincón disponible en la esfera pública. Otros estudios ${ }^{2}$ nos permiten también observar cómo en los momentos de ausencia o disolución de su especificidad, la pregunta constante sobre el vínculo entre arte y política expresó la necesidad de llenar el "vacío de sentido" que siguió a la desmovilización forzada de los setenta, y luego a la subsecuente desmovilización neoliberal que configuró el modelo de comportamiento ciudadano promovido durante la transición. En ambos casos el repliegue de la sociedad, expresado igualmente en el reatrincheramiento de la creación artística dentro de sus parcelas lingüísticas y disciplinares "seguras", expresa la crisis y disolución del quehacer político de masas instalado durante los sesenta. Una relación entre artistas y política cuyo anclaje dinámico con un proyecto popular de masas le otorgaba un sentido y objetivo, un referente cada vez más desdibujado a partir de la crítica cultural de inicios de los ochenta, cuando su influencia había finalizado abruptamente hace casi una década.

La revitalización de los debates sobre arte y política en años recientes en el ámbito de la investigación contemporánea (2008-2018) demuestra un deseo amplio en la escena del arte chileno por volver al pasado tanto en búsqueda de referentes como a desmitificar ideas hasta ahora totémicas, pero que sin embargo en la actualidad ya son incapaces de explicar concretamente cómo las/los artistas chilenos expresaron durante los sesenta la pertenencia e identificación de sus prácticas a las acciones y discusiones políticas generales de su tiempo. A partir de ciertos proyectos curatoriales ${ }^{3}$, este último aspecto -el de la identificación política y la afiliación a entidades colectivas- ha vuelto a cobrar protagonismo en la investigación sobre arte contemporáneo, otorgando un nuevo sentido a coordenadas orgánicas e institucionales que hasta hace una década eran parte de las anécdotas apenas mencionadas sobre un artista. Ello nos permite volver a la idea planteada por ciertos sectores del arte durante los sesenta, en la cual el abordaje de lo político desde el lenguaje artístico se presenta justamente en momentos en que la frontera entre política y sociedad es más tenue: cuando es menos efectiva como sesgo, más constitutiva de un espacio de residencia e identificación de lo nuevo.

En este sentido, y pese a la constante movilidad de su significado que se define incluso dentro del mainstream como sinónimo de "arte latinoamericano", es necesario advertir que la relación histórica

\footnotetext{
${ }^{1}$ Destacamos particularmente a algunos de estos trabajos por su sensibilidad particular a la hora de repensar el vínculo entre arte y política en un contexto de movilización social: Fernanda Carvajal, "Yeguas”, Santiago, CEDOC Artes Visuales / LOM Editores, 2011, pp. 13-45; Nicole Cristi y Javiera Manzi, Resistencia gráfica. Dictadura en Chile: APJ - Tallersol, Santiago de Chile, Lom Editores, 2016; Javiera Manzi, Carolina Olmedo y María Yaksic, "A la calle nuevamente. Gráfica y movimiento estudiantil en Chile, 2001-2016”, I Taller Casa Tomada: Jóvenes y espacio público, La Habana, Casa de las Américas, 2017; Consuelo Banda y Valeska Navea comp., En marcha. Ensayos sobre arte, violencia y cuerpo en la movilización social, Santiago, Adrede Editora, 2013.

2 En esta segunda perspectiva destacamos en ensayo de Carla Machiavello, "Vanguardia de exportación: la originalidad de la 'escena de avanzada' y otros mitos chilenos”, Santiago, CEDOC Artes Visuales / LOM Editores, 2011, pp. 79-105; así como los artículos que conforman el libro I. Szmulewicz ed., Arte, ciudad y esfera pública en Chile = Art, City and the Public Sphere in Chile, Santiago, Metales Pesados, 2015.

3 Ejemplo de esto es el abordaje del Movimiento Pro-Emancipación de las Mujeres de Chile - MEMCh como punto de finalización de la exhibición Desacatos: prácticas artísticas femeninas, 1835-1938, destacando la dimensión militante y política de artistas que hasta la contemporaneidad permanecen desafectadas de un relato general de lo político y su aportación en éste. Gloria Cortés ed., Desacatos: prácticas artísticas femeninas, 1835-1938, Santiago, Museo Nacional de Bellas Artes, 2017, cf. http://www.mnba.cl/617/articles-79406 archivo 01.pdf (consultado el 28 de marzo de 2018)

4 En palabras del teórico del arte y artista uruguayo Luis Camnitzer, esta sinonimia oculta la densidad de la histórica relación entre las producciones artísticas latinoamericanas y una función social del arte, generándose en lo contemporáneo un ejercicio normativo desde el modelo institucional sobre gestos que hasta entonces pertenecían marginados de cualquier museificación (2007: 14-15, 16). Sin embargo, y ante estudios más recientes como el realizado por la investigadora en cultura visual Claire F. Fox en torno a la acción cultural de la Unión Panamericana en la región, sabemos que los artistas formaron parte activa de
} 
entre arte y política en América Latina excede por mucho su actual identidad al interior del mercado del arte e, incluso, su histórica identificación cultural con la izquierda del siglo XX. Sus prácticas explícitas se remontan al siglo XIX, cuando la función otorgada al arte por la modernidad fue la invención de una "tradición cultural" para las noveles naciones latinoamericanas ${ }^{5}$, y se fortaleció durante la primera mitad del XX paralelamente en los modelos del arte revolucionario mexicano y el panamericanismo cultural promovido por los Estados Unidos como estrategia diplomática ${ }^{6}$. A mediados de siglo, la relevancia que la revolución cubana otorgó a los aspectos culturales y la temprana fundación de Casa de las Américas (1960) como espacio de contacto cultural e intelectual abierto a la izquierda del continente configuró un otro modelo de relaciones entre arte y política. En un contexto mercantil-global de las artes visuales, donde las posiciones otrora resistentes parecen ser rápidamente integradas y convertidas en objetos a la venta, el provocador gesto del teórico uruguayo Luis Camnitzer de incluir al MLNTupamaros en su genealogía del arte político latinoamericano ${ }^{7}$ no hace más que forzar la pregunta sobre cómo definir de manera autónoma e histórica los límites de un arte político como producción 'endémica', así como también a la puesta en consciencia de qué elementos son los que cruzan el desarrollo intelectual de nuestra región y a los debates sobre aquello que ha sido catalogado como 'arte político' en la historia reciente.

Respecto de este último aspecto y su transformación como categoría a lo largo de las décadas del Estado del compromiso, la dictadura y la postdictadura en Chile, el escrito que desarrollaremos a continuación aborda específicamente dos referentes o hitos formadores de significado para quienes formaron parte del ámbito artístico local durante el periodo, al que decidimos presentar -provocadoramente- invirtiendo el marco de lectura a 1988-1968: la figura del artista comprometido con la construcción revolucionaria de los "largos sesenta" (cuyo despliegue excede cualquier perspectiva conservadora en términos de unidad estética, valórica o generacional ${ }^{8}$ ) y aquel emergido a partir de la 'ruptura de sentido' del horizonte socialista a nivel internacional. Este último definido tanto por el declive político, intelectual y cultural del eje soviético (URSS-Cuba), como por la progresiva separación entre los intelectuales y la política, consolidada -entre otros factores- por la ilegalización de los partidos políticos como práctica dictatorial en el Cono Sur (1973-1990). En este último referente, nos detendremos en ciertas voces particularmente expresivas de esta intelectualidad crítica de la primera transición, que desde la radicalidad teórica operaron como una suerte de memoria editorializada de los sesenta por y para el proceso de renovación socialista iniciado hacia fines de la dictadura, y continuado en los siguientes años cercanos a las revueltas estudiantiles más recientes (2006-2011). Como caso

lecturas que vincularon al arte latinoamericano a un carácter político de carácter normativo desde mucho antes que el tiempo contemporáneo aludido por Camnitzer, ello tomando en cuenta las acciones diplomático-culturales emprendidas por los Estados Unidos a partir de la guerra española-cubano-estadounidense de 1898, así como la actualización de esta práctica en el contexto de la postguerra. Es en este periodo en que primero a través de la exaltación de un ideario indigenista-tropicalista, y luego en la promoción del arte abstracto, el paradigma panamericano robaba la idea de América Latina al alicaído muralismo mexicano, que hasta entonces había protagonizado el vínculo entre arte y política a lo largo del continente. cf. Luis Camnitzer, Didáctica de la liberación: arte contemporáneo latinoamericano, Montevideo, Centro Cultural de España, 2007, pp. 14-17; Claire F. Fox, Arte panamericano: políticas culturales y guerra fría, Santiago de Chile, Metales Pesados, 2016, p. 30-34.

5 Adelaida De Juan, “Actitudes y reacciones” [1974], Damian Bayón ed., América Latina en sus artes, México D. F., UNESCO / Siglo XXI Editores, 1983, pp. 34-44, 38-39.

6 Fox, op. cit., 17-18, 33-34.

7 Camnitzer, op. cit., pp. 65-83.

8 Aquí haremos propia la perspectiva de abordaje disciplinar propuesta por el historiador del arte griego Nicos Hadjinicolaou, en la cual la metodología materialista de aproximación al fenómeno artístico busca desmontar las anteojeras de la función burguesa-tradicional de la historia del arte y su autonomía (relativa a la "historia de los artistas", los "periodos artísticos" o la "historia de las obras de arte"), para abrir paso a una redefinición de este ejercicio en la historia del campo de las artes visuales en tanto estudio del ámbito cultural, social y político en el que éstas se desenvuelven. A partir de esta perspectiva, la his toria política general no se vería "ensanchada" o "ilustrada" por el relato particular de la historia del arte, sino que redefinida y en constante tensión / interpelación respecto de la observación de las actorías del arte como partícipes y aportes activos del proceso de construcción de subjetividades sociales, políticas e históricas de su tiempo. Nicos Hadjinikolaou, Historia del arte y lucha de clases, Buenos Aires, Siglo Veintiuno Editores, 2005, pp. 22, 46, 59. 
ejemplar de esta producción de discurso durante el proceso de renovación socialista, marcada por la actitud penitente respecto del pasado militante en el ámbito del arte, analizaremos el ensayo Lo político en el arte: arte, política e instituciones (2009) de la teórica del arte francochilena Nelly Richard ${ }^{9}$. Como veremos luego, esta separación buscaba entonces exculpar al pensamiento crítico de izquierda sobre el cripticismo de sus formas y el abandono de sus militancias en pos del atrincheramiento académico, contexto en el que se reclama para la producción artística una autonomía marcada por la renuncia a la acción política en favor de una retaguardia cultural, poética y reflexiva.

Del mismo modo que en 1983, Richard reformuló recientemente ${ }^{10}$ esta lectura, actualizando la separación entre lo político y lo social propuesta por la teoría de los movimientos sociales durante los ochenta. Entonces, el libro Lo social y lo politico. Un dilema clave del movimiento popular (1985) del sociólogo Rodrigo Baño fue perfilador tanto en la adopción de la perspectiva 'touraineana' de separación de estas dos esferas ${ }^{11}$, como en la subsecuente renuncia al marxismo como visión de totalidad de la izquierda ${ }^{12}$. Todo esto en un contexto chileno marcado por el retorno de cientos de políticos e intelectuales desde el exilio. En un pensamiento afín a estos valores, la 'escena de avanzada' perfilada en el texto de Richard aparece representada en oposición al intelectual orgánico, más cercana a la "política de los márgenes" que rompe con la vía "institucionalista" desplegada por la izquierda nacida de la experiencia del Frente Popular (1938-1948). Durante el proceso de renovación, el intelectual crítico se asume libre de las ataduras militantes que signaran el fracaso del proyecto emancipatorio de los sesenta, pero a la vez anunciaba la muerte del sujeto político del socialismo del siglo XX (obrero, popular, antagonista, intuitiva o formadamente consciente de su posición en la lucha de clases), así como la imposibilidad de la imaginación colectiva. La imagen del artista comprometido con la política de los frentes populares, de una riqueza y diversidad mucho más extensa, se vio en este contexto reducida al protagonista del fracaso de la vía institucional, que para el caso del arte fue -como para muchos otros escenarios abiertos durante el gobierno popular- el conjunto de las formas culturales promovidas en lo público por los referentes del Partido Comunista de Chile (PC). Al observar el círculo de artistas afiliados al comunismo durante los sesenta, la separación entre lo definido como "político" y lo definido como "militante" resulta imposible a la hora de observar sus obras y trayectorias. Experiencias que en el contexto de 1983 remitían unívocamente a las identidades de los partidos políticos derrotados, haciendo necesario el decretar la muerte de la cultura militante ante su imposibilidad de comprender las transformaciones que se sucedieron en el mundo durante de manera acelerada en la segunda mitad del siglo XX. Ante esta crítica, buscaremos distinguir particularmente cómo se dieron estos debates al interior de la izquierda durante la Unidad Popular -al que reconocemos como "nuestro propio" 68-, mostrando la riqueza de formas de abordar la relación entre arte y masas que existió dentro de distintos contextos militantes.

Propuesto este itinerario, este escrito analizará el desarrollo de este vínculo en relación a la escena artística de los sesenta, tanto en los hechos de su tiempo como en los discursos históricos

9 Nelly Richard, Márgenes e instituciones: arte en Chile desde 1973 [1983], Santiago de Chile, Metales Pesados, 2007, p. 21.

10 Nelly Richard, Lo politico en el arte: arte, política e instituciones", E-misferica no. 6.2, Nueva York, Hemispheric Institute / NYU, 2009, http://hemisphericinstitute.org/hemi/es/e-misferica-62/richard (consultado el 25 de marzo de 2018).

11 En 1978, Touraine afirmaría en diversas conferencias realizadas alrededor de Europa que la separación entre las organizaciones políticas y aquellas conformadas desde la sociedad sería visible en que "en casi todos los países del mundo se están formando nuevos movimientos sociales de oposición cultural que evidencian un tipo de crítica a la política teórica y quieren definir su propia estrategia". Estos se formarían "contra el poder y del Estado de control", pues "con el cambio de generaciones se desarrollan unas corrientes de opinión que no se definen hacia el poder. De esta forma se crean espacios políticos autónomos entre el mundo de la guerra y el mundo de los movimientos sociales. Esto se puede apreciar en la transformación de los partidos en un partido instrumental y en el nuevo papel de los sindicatos, en resumen, a un concepto limitado de la política". cf. Fernando Samaniego, "Alain Touraine: los movimientos sociales se desvinculan de la política", El País, domingo 14 de abril de 1974, Madrid, cf. http://elpais.com/diario/1978/04/14/sociedad/261352807 850215.html (consultado 25 de marzo de 2018).

12 Luis Thielemann, "El Movimiento Popular y la historiografía en Chile: Elementos para un balance a 40 años del Golpe de Estado”, Revista de Historia y Geografía no. 29, 2013, pp. 105-130, p. 115. 
construidos sobre éstos desde el arte y la crítica cultural dos décadas más tarde, durante la dictadura cívico-militar. Con este ejercicio buscamos profundizar en los referentes artísticos existentes en la época (equivocadamente reducidos en diversas lecturas al clivaje entre muralistas y conceptualistas), así como aclarar la naturaleza de las afirmaciones que a partir de los ochenta buscaron simplificar o esquematizar las aportaciones de los artistas 'comprometidos' con la izquierda chilena a lo largo del siglo.

Desde una perspectiva actual, nuestras consideraciones sobre el arte y la política durante la década del sesenta desarrolladas a continuación arriesgan ser calificadas como explicación o excusa que matiza el viraje cultural del comunismo a mediados del siglo XX y las acusaciones del pensamiento crítico acerca de este proceso en Europa y América Latina ${ }^{13}$. Alejados de ello, buscamos otorgar claves de lectura para las obras y discursos "materialmente existentes" en los sesenta, así como una breve perspectiva sobre la hegemonía cultural de la izquierda en el arte durante el '68 chileno'. Esto con el fin de revisitar ciertas caracterizaciones emblemáticas del arte militante de los sesenta realizadas durante la dictadura y la primera transición, que en un contexto de producción intelectual 'subterráneo'14 (19781982) devino en un proceso local que denominaremos de 'estigmatización de las militancias': la instauración de un régimen de sentido del intelectual post-orgánico a partir de la derrota de las fuerzas sociales del '68 expandido', caracterizado por su marginación del espacio social (separación sociedadintelectualidad) y el ejercicio de la redención y/o crítica pública respecto a la anterior pertenencia a las identidades militantes (separación sociedad-práctica política).

\section{8: la estigmatización de las militancias}

En 1986, la publicación de Márgenes e instituciones: arte en Chile desde 1973 (MI) ${ }^{15}$ iniciaba una nueva etapa en la escena artística local de la dictadura. A partir de este ensayo extendido a lo largo de diez apartados, la teórica del arte de origen francés Nelly Richard instalaba uno de los discursos más duraderos y revisitados sobre la metamorfosis sufrida por las artes visuales durante la dictadura y la transición a la democracia. Un análisis del estado de la escena artística local a más de una década de iniciada la dictadura de Pinochet, así como también un balance político sobre el pasado reciente de la intelectualidad de las artes y las humanidades en Chile, explicitando una perspectiva afiliada a la crítica situacionista y al dependentismo en el arte y la política ${ }^{16}$, adoptados en confrontación con los lineamientos de las lecturas del marxismo-leninismo. Del mismo modo, a partir de lo visual ${ }^{17}$, la teoría

13 Sobre este tema recomendamos el extraordinario ensayo que Boris Groys publicó en Cuba sobre la historia del arte soviético. cf. Boris Groys, Obra de arte total Stalin, La Habana, Criterios, 2008.

14 Tomando como referente este concepto que la investigadora brasileña Cristina Freire elabora a partir de la definición inicial del artista carioca Hélio Oiticica (1969), el espacio ‘subterráneo' del arte sería aquel que se despliega en ciertas tácticas que en un contexto autoritario (de censura, persecución, restricción y privatización de la esfera pública) sostienen un ideario estratégico de libertad para los artistas latinoamericanos en resistencia o en el exilio. Como respuesta al underground de la escena euronorteamericana, lo subterráneo constituiría una sub-trama de supervivencia del arte y la intelectualidad en su función de crítica política a partir de la constitución de una comunidad imaginaria de la resistencia como sustituto del ejercicio político proscrito. Cristina Freire, “Apuntes sobre el arte subterráneo en Latinoamérica, 1960-70”, Sistemas, Acciones y Procesos 1965-1975 (ed. Rodrigo Alonso), Buenos Aires, Fundación Proa, 2011, pp. 42-47, cit. pp. 41-42.

15 La primera edición de este texto es su publicación en la revista australiana Art \& Text en 1986, que para efectos de este análisis consultaremos por vía de la tardía edición del texto como libro realizada en 2007 por la autora con Editorial Metales Pesados. cf. Nelly Richard, "Márgenes e instituciones: arte en Chile desde 1973”, Art \& Text, Melbourne, 1986.

16 Richard, op. cit., Márgenes..., p. 10.

17 El énfasis en lo visual remite a la producción de imágenes, atrayendo nuestro interés no sólo a las disciplinas identificadas durante la modernidad con el campo de las artes plásticas (pintura, escultura, gráfica), junto a las formas de la neovanguardia artística del siglo (happening, performance, arte de acción, arte conceptual, entre otras) y la fotografía, sino que también hacia aquellas capaces de producir imágenes por su propios medios y las que portan en su producción con métodos de producción / reproducción técnica de la imagen: la arquitectura, el diseño, las artes aplicadas y las artes corporales son un ejemplo del primer grupo; mientras que las artes mediales, audiovisuales, la publicidad y la cultura de masas (cine, televisión, lectura de bolsillo) lo son respecto del segundo. 
de Richard se adentra en la interpretación del rol de los intelectuales chilenos desde la destrucción del presente, así como en su humana recomposición en el contexto dictatorial.

Desde la posibilidad de reconstrucción "a partir de ruinas" ofrecida como proyecto político de las vanguardias históricas, la adopción de los artistas de las estrategias neovanguardistas -centradas en la irrupción e intervención del cotidiano- y el abandono de las formas identificadas con la cultura de izquierda -entonces proscrita- son presentadas por este escrito como condiciones de supervivencia. En su propuesta, la autora adopta la visión de la 'escena de avanzada' como un sujeto particular entre los emergidos en este restringido escenario cultural: un espacio social e intelectual aglutinado en torno a las prácticas neovanguardistas que -aunque confrontado al discurso autoritario en sus reflexiones- se distingue del campo artístico e intelectual abierto durante la Unidad Popular (UP), así como de cualquier filiación directa a la expresión cultural de la izquierda partidista. Es en este último aspecto -el de los símbolos de la izquierda- en el que se basa su principal diferencia respecto de esta alteridad 'comprometida' ${ }^{18}$, pues como generación intelectual inmediatamente posterior al golpe interpreta la derrota política del socialismo también como la deslegitimación y puesta en crisis del pensamiento marxista en toda su amplitud, incluyendo el campo cultural a manos de la censura. Al estar las antiguas formas de expresión cultural de la izquierda indefectiblemente atadas a una práctica política en declive, Richard las juzga incapaces de generar nuevos sentidos sociales ante su destrucción: "una vez desarticulada la historia y rota la organicidad social del sujeto, todo deberá ser reinventado, comenzando por la textura intercomunicativa del lenguaje que, habiendo sobrevivido a la catástrofe, ya no sabe cómo nombrar los restos" ${ }^{19}$. De este modo, la principal tarea del arte emergido de la ruptura es la reconstrucción de estos lazos de sentido entre los sujetos desarticulados por el autoritarismo, y no el resguardo de las anteriores identidades políticas que entonces no tenían mayor futuro.

En esta lectura del escenario político-intelectual, la autora solidificaba una propuesta de identificación generacional de la neovanguardia ya habilitada por la escritura de su primer libro. Cuerpo correccional $(1980)^{20}$, en torno al arte de performance de Carlos Leppe, abordaba "lo político" desde la defensa de las formas contemporáneas -el arte de acción-, evidenciando su "opacidad de sentido" y disidencia respecto de los valores "oficiales" de la dictadura. Del mismo modo, esta 'avanzada' artística testimoniaba en su propia existencia el persistente deseo de liberación intelectual, política, social y sexual: ideal reclamado en la dictadura, pero también en la crítica al marxismo exaltada durante el '68'. Parafraseando sus dichos posteriores sobre estas ideas ${ }^{21}$, el paso en sus relatos del individuo neovanguardista ("tú") de Cuerpo Correccional a la generación de la 'avanzada' ("nosotros") en Márgenes e Instituciones (1986) expresa el tenor del momento de su escritura (1986), en el cual se hizo urgente para quienes integraban la 'avanzada' manifestar su existencia independiente frente a la "amenaza de absorción" implícita en la llegada de los artistas militantes desde el exilio. Así, Richard sitúa a la 'avanzada' escindida por igual de "la oficialidad represora de la cultura dominante" y de "la historia en negativo de sus víctimas, cuyo relato nacional-popular exbibia una monumentalidad de la resistencia que ocultaba las fisuras del sentido"22.

Así mismo, aquello que se perfila en el libro como una defensa a los frágiles lenguajes y estructuras de sentido construidos por la 'avanzada', también se vuelca a partir de sus primeras páginas en la defensa política frente a la crítica de los "retornados". En la medida que las producciones artísticas de la 'avanzada' no son explícitas como las acciones de los artistas exiliados en las brigadas antifascistas y el Museo Internacional de la Resistencia Salvador Allende (MIRSA), ni como la producción de los

18 Richard, op. cit., Márgenes..., p. 22.

19 Ibid., p. 16.

20 Nelly Richard, Cuerpo correccional, Santiago de Chile, Francisco Zegers Editor, 1980.

21 Nelly Richard, "Todo comenzó así”, Punto de fuga s/n, Santiago de Chile, Estudiantes de Historia y Teoría del Arte de la Universidad de Chile, 2015, http://www.revistapuntodefuga.com/?p=1872 (consultado el 25 de marzo de 2018).

22 Richard, op. cit., Márgenes..., pp. 21-22. 
gráficos comprometidos de la resistencia del inxilio ${ }^{23}$ intelectual ${ }^{24}$, el discurso se torna su espacio de imaginación y defensa política:

"Este arte -de impulso agitativo- no se topaba casi nunca con la producción de la 'avanzada' porque las ocupaciones territoriales de cada sector eran completamente diferentes. Mientras que el arte popular de las organizaciones de masa ocupaba espacios comunitarios alternativos, las obras de la avanzada apostaban a que su crítica institucional ganara visibilidad pública en los espacios disponibles de exhibición para desafiar el poder y la censura desde una oblicua estrategia de pliegues e interferencias" 25 .

"El arte de la 'avanzada' se sitúa en franca contraposición al régimen militar, pero, a la vez, se ubica en una marginalidad polémica frente a las organizaciones militantes de la cultura opositora... No le resultó funcional a los bloques de recomposición democrática que armaban el circuito antidictatorial" 26 .

Esta defensa respondía también a los 'usos no previstos' de las producciones de la 'avanzada' por parte de la crítica cultural de derecha alojada en El Mercurio, que destacó los aspectos formalistas y cristianos en desmedro de aquellos plenamente políticos en la poesía de Raúl Zurita ${ }^{27}$. La crítica de la izquierda a la ambigüedad comunicativa de la neovanguardia es abordada en las páginas de MI a modo de reacción ante los contenidos que se denominarán como "ideológico" y "denunciante-testimonial"28, por tanto externos a los medios "propios" del arte, desconociendo la necesidad de comunicación social como uno de estos materiales.

En un moldeamiento excluyente respecto del 'compromiso', para Richard la expresión artística de la 'avanzada' encontraría legitimidad al plantearse la tarea de disentir del "consenso ideológico-popular de lo nacional' 29 construido durante la UP y legado como una ruina a la izquierda a los militantes de su época, declarando de manera benevolente la esterilidad de las producciones contestatarias que aún anclaban sus prácticas en el desaparecido proyecto de la UP en este enlace entre pasado y presente. A las agrupaciones identificadas en esta última esfera las definía en su presente como "orgánicamente dependientes del militarismo combatiente de una izquierda contestataria que trabajaba en la semiclandestinidad y cuyo arte se dejó sobredeterminar por su referencia ilustrativa a la contingencia de las luchas nacionales" 30 . En este contexto, la enunciación de lo "ideológico" a lo largo de MI como una 'realidad ficcional' de la izquierda partidaria contrapuesta a la "realidad real" de los márgenes no hace más que ratificar al interior del análisis de Richard la separación entre lo político y lo social (promovida por Arendt en la filosofía y Touraine en la sociología), concibiendo a la teoría política comunista como un producto sin anclajes materiales concretos en la sociedad. En algún grado, esta acepción de "ideología" en relación al marxismo como paradigma de análisis busca precisamente su deslegitimación como ciencia social y como proyecto político popular, reduciendo su incidencia a la esfera partidista que caracteriza a la particularidad del marxismo-leninismo. Para el caso de la escena artística descrita por Richard, oblicua y metafórica a razón forzada, frustró el "reduccionismo ideológico de la cultura militante que quería traducir y reducir el arte a un

23 Tomamos la figura del inxilio de los estudios sobre la postguerra española, donde este vocablo se utilizó laxamente para designar tanto a la militancia en clandestinidad como a los intelectuales de izquierdas "que no aceptaban la doctrina oficial" del régimen franquista, y que "en la propia patria son extraños, perseguidos y señalados". Angelina Muñiz-Huberman, El canto del peregrino. Hacia una poética del exilio, Barcelona, Gexel / Universidad Autónoma de Barcelona, 1999, p. 85.

24 Sobre la resistencia cultural de la izquierda en el inxilio, recomendamos el estudio Resistencia gráfica de Nicole Cristi y Javiera Manzi, que caracteriza el trabajo de arte público realizado por el Taller Sol (1977-) y la Asociación de Plásticos Jóvenes (19791987) durante este mismo periodo. cf. Cristi y Manzi, op. cit.

25 Richard, op. cit., Márgenes..., p. 26.

26 Ibid., pp. 21-22.

27 Ibid., p. 33.

28 Ibid., pp. 21-22.

29 Ibid., p. 20.

30 Ibid., p. 26. 
simple realismo social de la contingencia": un ejercicio de calce puramente temático de la realidad a "los significados predeterminados del repertorio de la izquierda tradicionap"31.

Mientras el campo de pertinencia de este arte "político-partidario" estaría definido tanto por esta "ideología de lo social" como por las conservadoras formas del comunismo sigloventista para abordar la realidad latinoamericana; el de la 'avanzada' se abriría a la experiencia de la dictadura como escenario de redefinición de las fuerzas sociales, esto en la búsqueda de las fisuras en lo que José Joaquín Brunner denominara como "la factibilidad del poder" o sus condiciones concretas de control social, distintas de sus aspiraciones (33) ${ }^{32}$. Mientras los objetos del arte de compromiso "calzaban" la realidad al molde de un determinado "repertorio de la irquierda tradicional", los de la 'avanzada' eran "dispositivos materiales de producción de significados" que buscaron, desde y para el arte, abolir de manera definitiva "la vieja práctica del impresionismo" de ilustrar lo real y convertirse ellos mismos en una realidad problemática ${ }^{33}$, para lo cual sobrevivir a la censura y circular en la esfera pública resultaba una condición de base.

No es casual el rescate de las posturas de Brunner y Oyarzún en 1986 frente al trabajo de Richard en el seminario FLACSO Arte en Chile desde 1973: Escena de Avanzada y Sociedad, inscribiendo a la 'avanzada' en un campo intelectual determinado por medio de su abordaje en un seminario que entonces operaba como una "liturgia" y "punto de encuentro" del círculo intelectual de la renovación socialista. Hoy podemos acceder a las intervenciones intelectuales en dicho evento a través de su reproducción en las últimas páginas de la edición de MI del año 2007, en la cual se agregan como "apéndice documental" y testimonial a través del cual en el libro "la crítica se convierte en historia" 34 . De este modo la presencia del texto de Brunner, principal impulsor de las teorías parciales como epistemologías de la transición contra la perspectiva de "totalidad desde la parcialidad" de la izquierda durante la UP, debe ser considerado como la exaltación en dicha coyuntura de referentes establecidos como modelos intelectuales para "transición" particular del pensamiento crítico ${ }^{35}$, en un proceso de atrincheramiento y desmovilización. La forma particular que este autor signa para esta transición en el ámbito artístico es el de la heroicidad de la "evasión" y puesta en crisis "testimonial" de los tres pilares de significación dentro del régimen autoritario chileno por parte de la 'avanzada': el mercado, la represión y la televisión ${ }^{36}$. Para Brunner, el deseo de los artistas de la 'avanzada' de marginarse del mercado, la tradición y la comunicación de masas signaría la decadencia del grupo, consumando el ideal de inutilidad política del arte que impulsaba su despolitización.

Volviendo al sesgo establecido por la autora entre lo "político" y lo "comprometido", este no sólo estableció en 1986 un "cordón higiénico" entre las motivaciones de ambas iniciativas culturales, sino que además las identificó como fuerzas polares y eventualmente incompatibles al interior de la izquierda en la crisis global del socialismo, valores que a su vez son transmitidos de manera directa a todas sus prácticas e ideas encausándolas en dos tendencias. Primero una "nueva izquierda", alineada con la exaltación de la libertad individual y la subjetividad, que se concibe como fragmentaria. También ¿una "antigua izquierda", identificada en la imagen del Partido Comunista de Chile (PCCh) y el discurso del marxismo-leninismo, que en su creación colectiva y deseo de perspectiva general deviene finalmente

31 Ibid., p. 21.

32 José Joaquín Brunner, "Campo artístico, escena de 'avanzada' y autoritarismo en Chile”, Arte en Chile desde 1973. Escena de Avanzada y Sociedad. Documento FLACSO no. 46, Santiago de Chile, FLACSO, 1987. Reproducido en Richard, Márgenes..., pp. 171-178.

33 Pablo Oyarzún, "Crítica; historia”, "Campo artístico, escena de 'avanzada' y autoritarismo en Chile”, Arte en Chile desde 1973. Escena de Avanzada y Sociedad. Documento FLACSO no. 46, Santiago de Chile, FLACSO, 1987. Reproducido en Richard, Márgenes..., pp. 161-170.

34 Oyarzún, op. cit, p. 162.

35 Los valores y significados atribuidos por Brunner a las transformaciones del campo cultural en dictadura pueden leerse en detalle en uno de sus trabajos previos: J.J. Brunner y G. Catalán, Estudios sobre cultura y sociedad, Santiago de Chile, FLACSO, 1985.

36 Brunner, Campo artístico..., p. 175. 
en el autoritarismo, la esterilidad intelectual y la derrota. Del mismo modo, estas dos perspectivas confrontarían dos visiones distintas sobre la historia desde la izquierda: "la Historia como continuum de sentido y como linealidad del discurso" promovida por la acción artístico-política de los exiliados, y "la concepción multilineal de una temporalidad desintegrada" que desde la 'avanzada' planteaba una nueva función social del arte, renunciando sin embargo a la constitución de un sujeto político determinado (22). Como resultado de este "moldeamiento por diferencia", Richard afirmó entonces como la 'avanzada' vivió igual riesgo en contextos que, aunque políticamente contrarios -el poder dictatorial y la izquierda marxista-, rechazaban y criticaban por igual el cripticismo de su producción en su falta de ilustratividad ideológica y, por tanto, en su marcada inutilidad política.

“Las obras de la 'avanzada' vivieron doblemente el riesgo y la incomodidad: el riesgo de ser capturadas por el aparato represivo de significación oficial del autoritarismo y, a la vez, la incomodidad de tener que resistirse a las directrices ideológicas de la cultura partidaria que le exigía al arte subordinarse ilustrativamente a los temas de la recuperación democrática. Son obras que combatieron los dos operativos de totalización del sentido que se realizaban bajo marcas políticamente contrarias (las del poder oficial, las de la izquierda ortodoxa). Ni la cruel historia oficial de los dominadores ni la dolorosa historia contra-oficial de los dominados (una historia construida éticamente- como reverso, pero igualmente lineal en su simetría invertida), eran ya capaces de orientar al sujeto cultural hacia alguna finalidad y coherencia del sentido"37.

[...] "Dichos referentes [la filosofía alemana y el postestructuralismo francés de la 'avanzada'] cayeron naturalmente bajo sospecha en un medio cultural cuya tradición de izquierda se muestra más bien reacia a las importaciones de la teoría europea. Las escrituras críticas de la 'avanzada' que trabajan con dichos referentes fueron objeto de una doble censura ejercida tanto por el oficialismo cultural... como por la sociología de izquierda y la prensa progresista"38.

Como volvió a afirmar en distintos textos posteriores, para Richard el arte producido en la esfera militante, no tan homogéneo como sí mecánicamente subordinado a la cultura comunista, incluso en la enunciación de su carácter -el compromiso, una de las identidades más relevantes dentro de la cultura de la UP- se construye entrecruzando pasado y presente, exhibiendo en la impostura ilegítima de la normalidad de sus formas y lenguajes la razón de su derrota. Su condición de ilegítima radica precisamente en la inviabilidad de sus argumentos en un escenario intelectual que se construye en el contexto como Intelligentsia, y ya no desde la idea del intelectual orgánico como "el intelectual de un grupo". Vale decir, el conjunto de los intelectuales como un espacio de producción de sentidos distinto y distinguible del resto de los grupos que conforman la sociedad, a lo cuáles alimentan y dirigen moralmente desde un rol específico: "El arte del CADA no invita al transeúnte de la ciudad a contemplar imágenes que derivan de un repertorio político-ideológico ya trazado, sino que lo interpela como actor de un transcurso intercomunicativo destinado a soltar la red de condicionamientos sociales que lo mantienen prisionero" (64-65).

Así, la emancipación del sentido a través del arte ya no es un gesto colectivo y público, ya fallido en la extinción del brigadismo, sino que personal y acontecido en la conciencia individual de los sujetos en un escenario dictatorial en el que coexisten los intelectuales que conforman la 'avanzada'. Esta interpretación entra en franca polémica con los artistas resistentes y retornados, tanto por esta perspectiva de la política en el arte como por proponer una crítica directa a las formas en que los artistas "comprometidos" políticamente plantearon a mediados de siglo la relación entre arte y realidad social: en esta línea, Richard declara la bancarrota de la gráfica "obrera" 39 como un punto de quiebre

37 Richard, op. cit., Márgenes..., p. 21.

38 Richard, op. cit., Márgenes..., pp. 56-57.

39 Aquí no nos referimos puramente a aquella gráfica de inspiración en los motivos del movimiento obrero, identificada con la prensa obrera de inicios del siglo XX, sino que a la idea de la obra reproductible como medio de democratización del acceso a las obras de arte: una de las posiciones empujadas y desarrolladas por los artistas comunistas durante la UP. Respecto de este tipo de producción artística, cf. Ernesto Saúl, Pintura social en Chile. Nosotros los chilenos no. 13, Santiago, Empresa Editora 
respecto al mercado del arte, el declive irreversible de la universidad como espacio de influencia y legitimación del discurso artístico, y la poca relevancia de las tentativas previas de inclusión de la fotografía y el collage a la superficie pictórica como por parte de los informalistas, como un ejercicio intelectual menos sistemático que el uso de la fotografía por parte de la 'avanzada' a fines de los setenta ${ }^{40}$.

La crítica plasmada en MI, y que esbozamos brevemente en las páginas anteriores, tuvo un profundo impacto en las pocas lecturas del periodo 1960-1980 construidas durante la transición ${ }^{41}$, al igual que las consecuentes revisiones y lecturas que la autora realizara entre 2005 y $2015^{42}$. Estas críticas se instalaron como una "historia de los hechos" a pesar de su escasa documentación y "campo visual" respecto de la escena del arte local en el exilio e inxilio, tornándose protagónica en los relatos académicos del arte sobre esta década. Contribuyó a dicho proceso la instalación de la experiencia de la 'avanzada' y sus protagonistas en la esfera de la enseñanza universitaria del arte en Santiago, así como también en las instancias vinculadas a las artes visuales abiertas por el Estado transicional. Sin perder de vista estos últimos aspectos, y su acceso incluso accidental a la categoría de oficialidad, muchos intelectuales de esta "crítica cultural" de los ochenta continuaron de ahí en más una activa defensa y constante actualización de dichos valores en los subsecuentes momentos de crisis ${ }^{43}$.

Actualizando el sesgo imaginario existente entre arte y militancia, y ya instalada a nivel internacional como una de las voces intelectuales más relevantes de la dictadura en Chile ${ }^{44}$, Richard refundó en clave latinoamericana esta formulación antagónica entre militancia y experimentalidad, confrontando tanto histórica como teóricamente a la 'avanzada' con la acción cultural de la esfera del 'compromiso' en el exilio. A partir de la exaltación de la pertenencia subjetiva a las colectividades, el discurso de esta autora se inscribe entre las elaboraciones de una izquierda radical post-militante, en la cual la trinchera del cuerpo propio se percibe como el único campo posible de expresión e interpretación real del yo para los artistas en dictadura. Más allá de la pertinencia de este debate, resulta interesante observar cómo en lo contemporáneo (un tiempo de movilización social) se continúa reafirmando la ausencia del cuerpo social en su conjunto. En ello resulta ejemplificadora una afirmación reciente (2015) de la autora en relación a la primera versión del escrito que dio origen a MI, difundido en la revista italiana Domus en $1981^{45}$, y cuya circulación internacional por cuenta propia:

“Transgredía, además [de la dictadura], el sentido común de la izquierda internacional que se mostraba solidaria de las luchas del Chile antidictatorial: una izquierda que se identificaba con la estética testimonial del arte del compromiso de la cultura militante, mirando

Nacional Quimantú, 1972; Eduardo Castillo, Puño y Letra: movimiento social y comunicación gráfica en Chile, Santiago, Ocho Libros, 2006; Isabel Jara, Usos sociales de las imágenes: iconografía de prensa de ferroviarios y metalurgicos chilenos, 1900-1930, Santiago, Universidad de Chile, Departamento de Historia y Teoría de las Artes, 2011.

40 Richard, op. cit., Márgenes..., pp. 41, 54, 44-45.

41 Aquí nos referimos a aquellas que postularon un panorama de campo, Justo Pastor Mellado ed., Chile 100 años de artes visuales: tercer periodo, 1973-2000, transferencia y densidad, Santiago, Museo Nacional de Bellas Artes, 2000; Nelly Richard, Claudia Zaldívar y Pablo Oyarzún eds., Arte y política, Santiago de Chile, Universidad ARCIS, 2005; Gerardo Mosquera ed., Copiar el Edén. Arte reciente en Chile, Santiago, Puro Chile, 2006; Galaz e Ivelic, op. cit.

42 cf. Richard, Zaldívar y Oyarzún eds., op. cit.; Richard, Lo político... op. cit.; Richard, Márgenes... op. cit.; Richard, Todo comenzó... op, cit.

43 Una visión crítica de estos valores asociados a la militancia en el presente es posible de leer en Carolina Olmedo, "Arte y Política 4 (fragmentos): notas para la generación de 2011 en artes visuales", RedSeca, 22 de mayo de 2017, cf. http://www.redseca.cl/arte-y-politica-4-fragmentos-notas-para-la-generacion-del-2011-en-artes-visuales/; Carolina Olmedo, "Ad Augusta per Angusta: el arte y su relación con el conflicto social", RedSeca, 26 de mayo de 2014, cf. http://www.redseca.cl/ad-augusta-per-angusta-el-arte-y-su-relacion-con-el-conflicto-social/

44 Ejemplo de ello es la invitación extendida a Richard en 2017 para dictar una conferencia magistral sobre este tema en el Museo Nacional Centro de Arte Reina Sofía en Madrid, y su nombramiento como curadora del pabellón chileno en la 56a Bienal de Venecia en 2015.

45 Paulina Varas, "De la circulación artística chilena a la circulación de la Escena de Avazada", ICAA Documents Project Working Papers no. 1, septiembre de 2007, p. 60. 
con recelo cualquier experimento neovanguardista como el de las performances de Carlos Leppe." 46

A un escueto cuerpo inicial de artistas identificados con su idea del 'compromiso' dentro de MI -los pintores Gracia Barrios y José Balmes, el gráfico y escenógrafo Guillermo Núñez, MATTA, la Asociación de Plásticos Jóvenes, el Grupo Signo y las Brigadas Ramona Parra-, Richard ha sumado en los años recientes a críticos de arte y artistas latinoamericanos como el crítico argentino Aldo Pellegrini y el pintor cubano radicado en Chile Mario Carreño. En las palabras de este último en el contexto de la UP, la autora pareció encontrar el mejor ejemplo de lo que, a su juicio, plasma nítidamente a la figura del artista militante de izquierda como promotor del estajanovismo productivista:

"Vemos que hay una pintura revolucionaria y una pintura para la revolución... Yo estimo que una pintura revolucionaria es aquella que ha creado un lenguaje formal, un lenguaje que le ha dado una independencia, y una pintura para la revolución es aquella que necesita hacer el artista como acto útil para la revolución"

Instalado en un rol ambiguo entre los campos enemigos y adversarios de la crítica cultural de izquierda, la obsolescencia de la creación militante estaría dada por su uso instrumental y agotado del arte en su dimensión propagandística, algo que además en la interpretación de Richard en MI se opone directamente a la maduración de la fallida neovanguardia chilena. Así, los artistas que por entonces retornaban desde el exilio, al no renunciar a la esfera problemática de su militancia y portar en ella la responsabilidad sobre el abrupto fin de la UP, continuarían sometidos a una instrumentalización del arte intensificada durante los sesenta y comprobada como fallida en la derrota del proyecto político socialista. En su análisis, ésta marcada estrechez ideológica del despliegue militante en el arte se vería actualizada en la acción de los retornados, quienes por entonces "propondrían por medio de directrices ideológicas la subordinación del arte a los temas de la recuperación democrática".

Los ecos entre esta descripción del artista militante y aquellas expresadas en los discursos del cosmopolitismo artístico promovido desde las entidades panamericanas a comienzo del siglo $\mathrm{XX}^{48}$, dan cuenta de los flancos más dañados del internacionalismo comunista y el discurso del marxismoleninismo a ojos del pensamiento crítico posterior a las revueltas de los sesenta. A partir de entonces, el antagonismo entre construcción colectiva y libertad en la esfera socialista, así como la negativa evaluación del campo intelectual y artístico del internacionalismo como "gigante" subordinado al estalinismo y la cultura estajanovista, serán comentarios frecuentes sobre la cultura comunista. En este sentido, esta crítica a la militancia intelectual y artística perfila a los sujetos como carentes de cualquier autonomía intelectual y artística, por tanto, sin proyecto a futuro.

En su visión (incluso actual), los sesenta son un escenario "cargado de ideologismo" y opacidades partidarias, en el cual el clivaje entre acción revolucionaria y autonomía del arte impidió tender puentes entre vanguardia y militancia. Así, la función del artista en el contexto de la militancia correspondería a la creación de maniobras simbólicas de carácter nacional-popular identificadas con la función propagandística (lo políticamente explícito) como un "realismo ilustrativo"49. La estrechez ideológica de la izquierda partidaria acusada por Richard en su relación con la cultura será uno de sus principales significados atribuidos a la militancia de izquierda en este ámbito durante las décadas de la transición democrática, instalando un sentido peyorativo hacia las formas de la transparencia política del

46 Richard, Todo emperó..., op. cit.

47 Mario Carreño citado en Osvaldo Aguiló, Plástica neovanguardista, antecedentes y contextos, Santiago de Chile, CENECA, 1983, p. 35. Cit. en Richard, Lo politico...

48 El ejemplo más recordado de esta perspectiva crítica es la fábula La cortina de nopal (1951), del mexicano José Luis Cuevas. cf. Fox, op. cit., pp. 225-239; José Luis Cuevas, "La cortina de nopal”, Ruptura s/n, México D. F., Museo Carrillo Gil, 1988, pp. 84-91. Archivo ICAA MFAH.

49 Richard, Lo político..., s/n; también en Richard, Márgenes..., p. 64. 
$\operatorname{artista}^{50}$. En la separación de un arte político "explícito" (propagandístico) y uno "poético", afianzando sus dichos en la radicalidad del pensamiento crítico de los sesenta, el ámbito crítico del arte forjado en las facultades de ciencias sociales y centros de estudios orgánicos -espacios de renovación intelectual durante este periodo- reivindicó la autonomía del lenguaje artístico y la independencia del trabajo intelectual como herramientas que permiten construir un espacio para el arte en la adversidad de la dictadura. En este contexto particular, de ilegalización de las organizaciones, intervención de instituciones y medios de comunicación, así como de privatización del espacio público por parte de las fuerzas armadas, la autora critica al ejercicio militante como estéril y declara la necesidad acelerada de encontrar un nuevo "arte político" en la construcción de sentidos que desde las relaciones poéticas, oblicuas y metafóricas abran un espacio de resistencia imaginaria.

En las páginas siguientes buscaremos revisitar algunas de las relaciones materialmente existentes durante los sesenta entre vanguardia artística y vanguardia política en Chile, a fin de aproximarnos desprejuiciadamente a este campo de relaciones entre los integrantes de la escena artística y sus identidades militantes y comprometidas. En esta línea, revisaremos algunos de los diversos roles que los artistas asumieron en su relación cotidiana con 'la política', perfilando el modo en que asumieron individual y colectivamente el "rígido" imperativo de Carreño de un 'arte para la revolución'. En su diversidad de respuestas, veremos que los artistas militantes -lejos de asumir pasivamente la producción de un "arte funcional a la ideología" perfilado en la crítica cultural de los ochentaanticiparon a confrontación de los valores del arte burgués a través de la exaltación del individuo integrado al colectivo del mundo que le otorgaba un medio para la transformación. Así, la confrontación del arte burgués con un "arte útil" pensado en las mayorías tomó múltiples formas muy lejanas de constituir un proyecto unívoco.

\section{8: el joven despierto}

Entre los casos englobables en un '68 latinoamericano', el de la escena del arte en Chile hacia fines de los "largos sesenta'51 y la Unidad Popular es sin duda uno de los más emblemáticos y ricos a la hora de ser analizados desde una perspectiva regional. Conformada por artistas locales "criollos" y de origen migrante, así como también por un sinnúmero de intelectuales refugiados en Chile durante los

50 Podemos encontrar otros ejemplos latinoamericanos respecto de la estigmatización de la esfera militante en el proceso de disolución del sujeto político de la izquierda en los escritos del curador paraguayo Ticio Escobar sobre el carácter subjetivista e individuante de la resistencia latinoamericana postsocialista, así como también en la mirada retrospectiva que Mari Carmen Ramírez realiza sobre el trabajo de Marta Traba, sobre la que destaca los aspectos de su performatividad discursiva y elocuencia (formales) por sobre los contenidos teóricos de su discurso (profundamente cruzado por el pensamiento dependentista), que marcados profundamente por la idea de resistencia en auge durante los sesenta, parecían en los noventa profundamente anacrónicos. cf. Ticio Escobar, El mito del arte y el mito del pueblo, cuestiones sobre el arte popular, Santiago de Chile, Metales Pesados, 2008; Mari Carmen Ramírez, "Sobre la pertinencia actual de una crítica comprometida", en Marta Traba, Dos décadas vulnerables en las artes plásticas latinoamericanas, 1950-1970, Buenos Aires, Siglo Veintiuno Editores, 2005, pp. 33-54.

51 El término "largos sesenta" tiene hoy amplia aceptación académica, entendiendo que "los sesenta" no representa una categoría cronológica, sino heurística (Sorensen). Los "largos sesenta" en el Cono Sur son aquellos años que referencian a una época histórica en común referenciada en los sesenta, pero que variará de acuerdo a cada línea histórica nacional o regional. Pese a su heterogeneidad, esta época latinoamericana estará marcada por intensos procesos de politización de masas y la instalación de un horizonte revolucionario, de transformación e integración social. Los inicios de esta época se remontan a la emergencia de los frentes populares y otros referentes de masas (en Chile, con la fundación en 1956 del Frente de Acción Popular y en 1957 del Partido Demócrata Cristiano), la gira de "buena voluntad" de Richard Nixon (1958) y el desarrollo de la revolución cubana (1959) como quiebres profundos en un régimen de sentido previo; y el final lo hallamos en el derrocamiento de Salvador Allende (1973), que iniciaría junto con el golpe de Estado en Uruguay (1973) y Argentina (1976) la clausura de América del Sur como un espacio de debate, refugio e imaginación política. cf. Diana Sorensen, A Turbulent Decade Remembered: Scenes from the Latin American Sixties, Stanford, Stanford University Press, 2007, p. 215; Óscar Terán, Nuestros. años sesentas. La formación. de la nueva izquierda intelectual en la Argentina 1956-1966, Buenos Aires, Siglo Veintiuno Editores, 1991. 
sesenta, la escena santiaguina (y de cercanías ${ }^{52}$ ) de las artes visuales tenía entonces un marcado carácter transnacional, conteniendo en sus formas concebidas como "políticas" a referentes provenientes de diversas fuentes: el cosmopolitismo norteamericano de los cincuenta y su interpretación del automatismo "mattiano"53, el "realismo intensificado" del informalismo en sus distintas versiones dentro del internacionalismo, la teorías cepalianas sobre el desarrollo y su respuesta -la teoría de la dependencia- venida desde Brasil en las valijas del exilio, el auge del pensamiento latinoamericano y antiimperialista que siguió a la revolución cubana durante los sesenta ${ }^{54}$, la expresión de la crítica postmoderna al sujeto político en los sesenta, la experimentalidad objetual y conceptual, así como los debates de las ciencias sociales y humanidades de la intelectualidad internacionalista a lo largo de todo ese periodo, entre otros. También se introducen al ámbito de pertinencia de las artes durante esas décadas las referencias de lo popular, lo masificado y la identidad obrera, que a partir de la década del cincuenta empiezan a entrecruzarse y disolverse ante la apertura de la pregunta por la especificidad latinoamericana.

El campo problemático ofrecido por este último aspecto, que Richard identifica durante los ochenta en el muralismo de las Brigadas Ramona Parra como producto del cruce de estos mundos, englobó durante los sesenta un vasto espacio social de carácter popular en emergencia, del cual eran expresión referentes tan disímiles como el Museo de Arte Popular Americano dirigido por Tomás Lago $^{55}$, los viajes recopilatorios de Violeta Parra y su Museo Nacional del Arte Folclórico Chileno ${ }^{56}$, la música folk-rock de Víctor Jara, el realismo de Neruda en Fulgor y muerte de Joaquín Murieta (1967) (y su sencillez junto a Ángel Parra en su Arte de pájaros, 1966), el cine experimental de Carlos Flores del Pino en Descomedidos y chascones (1973) ${ }^{57}$ y el cartel dedicado a Quinchamalí diseñado por Guillermo Núñez, entre muchas otras expresiones comprometidas de la época.

Incluso dentro de la producción individual de ciertos artistas esta diversidad emergió en diferentes estéticas incluso contradictorias entre sí ante un análisis meramente formal, aunque muy emparentadas entre ellas a través de una serie de ideas y valores compartidos durante su desarrollo. Un ejemplo de ello es la trayectoria de Gracia Barrios, que desde el abstractismo expresivo de origen europeo (Acontece, 1967) transita hacia el textil artesanal y el patchwork (Multitud III, 1972) en la construcción de sus características 'siluetas' en el lapso de una década. En otras experiencias, la militancia o cercanía partidista buscó expresar con osadía plástica las necesidades del mundo real más

52 Siguiendo la propuesta de Justo Pastor Mellado, desde mediados del siglo XX la constitución de escenas artísticas en Chile se dio puntualmente en aquellos enclaves donde existían condiciones básicas para la emergencia de espacios de lenguaje y "presencia efectiva" de las artes en la esfera pública. Recomendamos observar detenidamente la mirada que Mellado ofrece de su ciudad de origen, Concepción, a quien instala a modo de escena modelo respecto de este tipo de "procesos de escenificación". cf. Justo Pastor Mellado, Escenas locales. Córdoba, Curatoría Forense, 2015.

53 Sobre una visión del panorama norteamericano que antecedió y acompañó los sesenta, cf. Fox, op. cit.; Serge Guilbaut, "Éxito: de cómo Nueva York les robó a los parisinos la idea de modernismo, 1948", Alonso, Rodrigo ed., Imán: Nueva York: Arte argentino de los años 60, Buenos Aires, Fundación PROA, 2010, pp. 37-65.

54 Destacamos respecto de este ámbito de estudio la exhibición realizada por María Berríos y Jakob Jakobsen acerca de la exposición "Del Tercer Mundo" realizada en el Pabellón Cuba, La Habana, en 1968. María Berríos y Jakob Jakobsen, The Revolution must be a school of unfettered thought, exposición en la 31a Bienal de Sao Paulo, 2014, cf. http://www.31bienal.org.br/en/post/1501 (consultado el 25 de marzo de 2018).

55 Constanza Acuña, Origen y devenir del Museo de Arte Popular Americano Tomás Lago, Santiago, MAPA, s/f, cf. http://www.mapa.uchile.cl/proyectos/index.php (consultado el 25 de marzo de 2018).

56 Actualmente desaparecido, el Museo Nacional del Arte Folclórico Chileno y el Departamento de Investigaciones Folclóricas dirigidos por Violeta Parra durante 1958 dependían de la Universidad de Concepción, que había contratado a la cantautora e investigadora en noviembre de 1957 para la realización de estas tareas gracias a las gestiones del poeta Gonzalo Rojas y el rector de la UDEC David Stitchkin. Parra fundó el Museo Nacional del Arte Folclórico Chileno el 22 de enero de 1958. Sobre el paso de Violeta Parra por Concepción y su vínculo con la universidad, referenciamos el trabajo de Fernando Venegas Espinoza, Violeta Parra en Concepción y la frontera del Biobio, 1957-1960: recopilación, difusión del folklore y desborde creativo, Concepción, UDEC / CNCA, 2017.

57 Carlos Flores del Pino, Descomedidos y chascones, Santiago, Departamento de Cine, Universidad de Chile, 1973. Cineteca Virtual de la Universidad de Chile, cf. http://www.cinetecavirtual.cl/fichapelicula.php?cod=34 (consultado el 15 de abril de 2018). 
que "dominar" o someter al arte a las reglas exógenas de la política, como expresa nítidamente el trabajo de Alberto Pérez en sus Barricadas (1965), que signan su afinidad política por esos años con la "guerra de guerrillas" del Che Guevara.

En este último ámbito se dieron distintas alternativas estético-políticas incluso dentro de un mismo contexto de militancia partidista, como fue el caso de la diversidad estética entre los artistas del PCCh a la hora de enfrentar el desmontaje de los bastiones de la tradición elitista y excluyente de la oligarquía chilena aún arraigados en la institucionalidad cultural pública. Esta como una de las experiencias más emblemáticas de radicalización de las artes vivida entonces, que configura una identidad orgánica de los artistas en torno a la imaginación de un rol social transformador, más una entre varias otras experiencias del mismo tipo. La composición heterogénea de un escenario local de este tipo vuelve imposible la disección de todas estas producciones en distintos tipos, categorías o gradaciones de "arte político" de acuerdo a su grado de cercanía con la práctica política formal, en la medida que ella -lejos de establecer una subordinación temática- proveyó a los artistas de nuevas audiencias y espacios de circulación respecto de su antiguo anclaje a la academia y el museo, así como de un nuevo lenguaje (el de la política de masas) que llevar a sus aulas y salas de exhibición como temática y objeto de inspiración.

Ante estos hitos, es claro que los sesenta son un momento fundacional dentro de las relaciones entre arte, política y sociedad en Chile, no pudiendo ser comprendidos sin atender al contexto de intensa y masiva participación de los sectores populares y medios en los procesos políticos en que se entraman las diferentes actitudes dentro del ámbito artístico orientadas a lo político. En un espacio intelectual de confluencia entre la diáspora intelectual de los exilios argentino y brasileño, la masificación y radicalización de la política, la emergencia del ideal cultural revolucionario, ¿Cómo concebir los efectos locales del "sesenta y ocho" en el arte dando cuenta de su mundialidad sin caer en el abismo de la totalización y la homogeneidad? Desde esa pregunta, el "sesenta y ocho" que perfilamos en el arte de este tiempo no tiene un afán 'globalizante' o integrador a un relato universal establecido, sino que más bien busca ser una prueba de los sesenta como un momento de acelerados cambios en la región y el mundo debido a la crisis general del modelo de industrialización. El vacío de sentido que siguió a la caída de los ideales modernos sostenidos por el modelo ISI hasta entonces implicó a la escena artística local en una intensa reflexión cuestionadora tanto de la construcción de relatos en el arte (basada en "movimientos" y "estéticas" distinguibles y sucesivas), como de la función social específica que el arte debía tener en un contexto revolucionario.

En este sentido, cabe destacar que para el periodo (1965-1973) una serie de factores que caracterizan a este proceso de radicalización para el contexto social específico de los artistas y críticos abordados por este estudio:

A - La emergencia popular y obrera en la política nacional y la esfera pública ciudadana, que se tradujo durante esta década en la identificación efectiva de los sujetos en las "identidades de clase" construidas por el marxismo, así como también en una recurrente referencia a la multitud popular y juvenil como protagonista de un nuevo ciclo de la modernidad. Respecto de este punto, se ha caracterizado al entorno social en que se desenvolvieron los artistas de los sesenta como un contexto definido por el predominio de la población juvenil y urbana ${ }^{58}$, dentro de la cual esta franja de creadores y agentes dialogaba y se identificaba. Esta "obtención de la voz propia" por parte de las mayorías -y dentro de ellas una generación de artistas- se expresó en el ámbito intelectual general con reacciones de angustia y entusiasmo, constituyendo una de las temáticas más relevantes dentro de la apertura de las artes a un contexto general de la política, y una de las preocupaciones centrales de gran parte de los artistas comprometidos.

B - El establecimiento de identidades aunadoras en los sectores medios profesionales, al cual pertenecen amplias franjas de artistas en los sesenta, y que aglutina en parte a experiencias como las del

58 Enzo Faletto, “Chile 1950-1973: transformaciones y conflictos”, Chile 100 años de artes visuales: segundo periodo, 1950-1973, entre modernidad y utopia, Santiago, Museo Nacional de Bellas Artes, 2000, pp. 51-67, p. 53. 
movimiento estudiantil en torno a la Reforma Universitaria y las de la intelectualidad crítica movilizada durante la UP en torno a los valores revolucionarios, a la cual sin duda pertenecen las trayectorias artísticas mencionadas en este estudio ${ }^{59}$. La apertura de los espacios institucionales del arte a sistemas "meritocráticos" de designación de autoridades durante los sesenta se mezcló con un "cosmopolitismo referencial" adoptado por estos sectores medios, que tanto desde discurso liberal como desde la izquierda recibían el imperativo de su internacionalización ${ }^{60}$. Un ejemplo de la implicación de estos valores en algunos hitos hacia fines de los sesenta es el nombramiento del pintor Nemesio Antúnez como director del Museo Nacional de Bellas Artes en 1969, quien en su programa de aproximación de artistas neovanguardistas ${ }^{61}$ consolidó el vínculo entre arte experimental ("lo más nuevo" en el campo artístico internacional) y proyecto moderno en el relato institucional de las artes. Sin desconocer la incorporación de Antúnez a su gestión y su propia obra de referentes populares (la alfarería de Quinchamalí y los volantines se habían vuelto temas recurrentes en su producción pictórica y gráfica ${ }^{62}$ ), lo cierto es que desde la "casa del arte" más importante del arte en Chile se promovió durante la UP un nuevo arte desanclado de la identidad de los sectores populares (entonces en pleno auge), mucho más cercano a la experiencia internacional y el gusto cosmopolita de los sectores medios ilustrados.

C - La instalación de un horizonte amplio y radical de transformación en torno a la idea de "revolución", y el posicionamiento de los intelectuales y artistas del continente en el papel de una vanguardia que vislumbra e imagina el mundo reivindicado por las luchas sociales ya realizado. En la adopción de la vanguardia como categoría proveniente de la política, pero también como identidad de acción artística vinculada a lo revolucionario, podemos observar la valoración extendida entre los artistas del continente -desde distintas militancias y también en la esfera del compromiso- de que el arte debía constituirse como una arena de confrontación y avance particular en la disputa ideológica general ${ }^{63}$. Esta acepción latinoamericana de la vanguardia desde el arte, sin embargo, traspasaba formalmente las identidades que separaban a las vanguardias históricas respecto de las neovanguardias en el contexto euronorteamericano, aproximando a los artistas de la izquierda partidaria en la región a las tendencias conceptuales y del pop, entonces miradas con sospecha por el resto de la intelectualidad de la región ante la denuncia constante de la existencia del imperialismo cultural. Tras estos conceptosfuerza, el contexto de transformación de finales del sesenta exaltaba la creatividad frente a una tradición que caracterizaría como lastre, y acudiría en sus producciones cada vez más recurrentemente al humor, el subconsciente, lo popular y la contingencia histórica como contextos opuestos a la trayectoria del arte racionalista de la modernidad clásica. Del mismo modo, en sus formas se promovía ciertamente la confrontación o "lucha de mentalidades" intelectuales en lo público, cuyo ejemplo más emblemático lo encontramos en los debates epistolares acontecidos en revistas emblemáticas de la izquierda

59 Respecto de estos mecanismos de constitución cultural, política y social de la llamada 'clase media', referenciamos el trabajo del historiador chileno Marcelo Casals, Middle Class and Dictatorship in Chile: Consent, Negotiation, and Crisis, 1970-1983, tesis para acceder al grado de Doctor en Historia de América Latina y el Caribe por la Universidad de Wisconsin-Madison, prof. tutor: Steve Stern, 2016. Parte de esta investigación fue expuesta por el autor en las XXII Jornadas de Historia de Chile, Universidad Austral, Valdivia, noviembre de 2017.

60 Cabe destacar aquí el impacto que tuvo el auge del arte abstracto norteamericano durante los cincuenta y los sesenta como un modelo a seguir por parte de América Latina en materia de internacionalización, así como también el panamericanismo cultural impulsado por la oficina de Artes Visuales de la OEA durante el mismo periodo. Como veremos, también el modelo de solidaridad impulsado en la región va a expresar una vía alternativa de internacionalización. cf. Fox, op. cit.; "Introducción". 61 Antúnez había sido becario Fullbright en 1943 y estudiado un master en la Universidad de Columnbia, y también agregado cultural de Chile en Nueva York durante el gobierno de Eduardo Frei Montalva (1964-1969) Emblemáticas son las intervenciones de los artistas Juan Pablo Langlois Vicuña (1969), Cecilia Vicuña (1971) y Luis Camnitzer (1972) durante su dirección, así como también ciertos referentes tanto del cosmopolitismo norteamericano impulsado desde el MoMA, como del discurso crítico y comprometido del exilio europeo de postguerra en Nueva York y los artistas jóvenes norteamericanos contemporáneos de su época (Hans Richter en 1970, Ulrich Welss, Alexander Calder y Gordon Matta-Clark en 1971).

62 Consejo de Monumentos Nacionales de Chile, Mural Quinchamali de Nemesio Antúnez. (1958), Santiago, CMN, 2011, cf. http://www.monumentos.cl/monumentos/monumentos-historicos/mural-quinchamali-nemesio-antunez

63 Ana Longoni, V anguardia y Revolución. Arte e izquierdas en la Argentina de los sesenta-setenta, Buenos Aires, Ariel, 2014, pp. 23-26. 
latinoamericana como Casa de las Américas en Cuba (1960-presente) y Marcha en Uruguay (1939-1973). En dicho horizonte de acción, los artistas se concibieron y fueron concebidos por su entorno como "ingenieros imaginarios" de un mundo por construir, así como también asumieron en su mano la transformación de los propios lenguajes y memorias históricas del arte en favor de los nuevos sujetos sociales.

D - La constatación en los sujetos de la época de una experiencia conjunta del tiempo contemporáneo y la valoración de la política nacional desde el prisma internacional, impulsada además por la experiencia transversal a distintas geografías de la revuelta social y la articulación cubana de la lucha tricontinental por medio de la acción cultural emprendida por la Organización de Solidaridad de los Pueblos de África, Asia y América Latina (OSPAAAL). Aquí conviene poner atención a las condiciones humanas y materiales que originaron estos contactos, sustentados principalmente en las experiencias internacionales de los artistas y la presencia de extranjeros y sus redes en nuestro, así como también a la guerra fría como el escenario de un primer momento de comunicación y posicionamiento global de las mentalidades intelectuales. También aquí cabe destacar la experiencia de la migración política en Chile, en particular el extenso arraigo republicano español ${ }^{64}$, que en su "chilenización" introdujo o "transfirió" 65 de manera directa -ya no dependiente del "viaje iniciático" al hemisferio nortelas reflexiones del arte europeo al espacio de producción latinoamericano. Por otra parte, el viaje formativo a los centros de la producción artística de Occidente (antes en Europa, pero que en los sesenta estaban ubicados también en grandes ciudades de los Estados Unidos) seguirá siendo un fenómeno central en la constitución de una experiencia de la condición de colonialidad por parte de estos artistas, que verán en su escasa o esquemática inserción al escenario artístico de estos centros una reactualización del sesgo en torno al arte latinoamericano como menor, atrasado o derivativo ${ }^{66}$.

A partir de estos factores, proponemos la observación de la escena artística santiaguina de los sesenta desde dos ejes de sentido crítico respecto de las anteojeras de la transición, en cuyo desmontaje nos permite observar la heterogeneidad práctica, referencial y discursiva del arte militante durante los sesenta, así como también la diversidad de sus anclajes sociales y asimilación del rol militante. De este modo, a través de estos lineamientos buscaremos matizar la idea de que durante la Unidad Popular existió un único y centrado proyecto de expresión cultural dentro de la izquierda, o un proyecto equivalente a cada una de las fuerzas que conformaron a dicha colectividad en su dimensión de coalición política: una perspectiva naturalizada en ciertos estudios sobre la búsqueda del horizonte socialista desde lo cultural ${ }^{67}$, mandato que ciertamente en el ámbito artístico no estaba trazado con claridad ni permitía articulaciones mayoritarias dentro del grupo conformado por los artistas metropolitanos de izquierda. Como ha afirmado la historiadora del arte Carla Macchiavello, si bien el imperativo de la época fue realizar un arte para el pueblo, en la elaboración de los diversos planes culturales de la UP 'los conceptos de 'pueblo', 'popular' y 'populismo' muchas veces se confundían, creando una resbalosa zona de traspasos entre el arte del pueblo, hecho por el pueblo y para el

64 Sobre la contribución de la migración republicana española al ámbito intelectual y político chileno, cf. Juliá Guillamon ed., Literaturas del exilio: Santiago de Chile, Santiago, SEASEX AECID / Centro Cultural La Moneda, 2007; Carmen Norambuena y Cristián Garay, España 1939. Los frutos de la memoria. Disconformes y exiliados. Artistas e Intelectuales Españoles en Chile 1939-2000, Santiago, Instituto de Estudios Avanzados IDEA USACH, 2002.

65 Tomamos la idea de transferencia trabajada por el crítico de arte y curador Justo Pastor Mellado, que alude en este trabajo a los medios en que el arte latinoamericano se concibe en constante "puesta al día" respecto del arte euronorteamericano durante los cincuenta y sesenta. Así, la transferencia refiere al momento del desplazamiento y asimilación de un discurso artístico de una geografía a otra, en un escenario de colonialismo cultural comúnmente determinado de norte a sur. A esta idea, Mellado contrapone la noción de densidad, que refiere al momento de emergencia de problemáticas y efectos propios dentro del ámbito artístico local a partir del primer proceso, generando en la fisonomía social y productiva del arte un aspecto discontinuo y heterogéneo. cf. Justo Pastor Mellado, "Historias de transferencia y densidad en el campo plástico chileno", Chile 100 años de artes visuales: tercer periodo, 1973-2000, transferencia y densidad, Santiago, Museo Nacional de Bellas Artes, 2000, pp. 8-23. 66 Camnitzer, op. cit., pp. 14-15.

67 Martín Bowen, "El proyecto sociocultural de la izquierda chilena durante la Unidad Popular. Crítica, verdad e inmunología política”, Nuevo Mundo Mundos Nuevos, 21 de enero 2008, cf. http://journals.openedition.org/nuevomundo/13732 
pueblo"68. La misma "oficialidad" de la presidencia allendista hablaba de un plan cultural trazado únicamente sobre las metas de generar un Instituto de la Cultura y el Arte y una convención de artistas a nivel nacional, así como una editorial del Estado que se cristalizó en la nacionalización de Zigzag e instalación de Quimantú ${ }^{69}$. El resto de las heterogéneas tentativas citadas en este estudio significaron la realización y desborde de estos gruesos lineamientos generales.

\section{Militancia y juventud como diversificación del "proyecto único" de la izquierda}

Abordada por la crítica cultural de los ochenta casi exclusivamente desde la identidad comunista, la esfera de la militancia es descrita como una realidad homogénea, rígida, y monolítica, que se comportaba durante la UP o como un "estalinismo de bajo perfil" (ejemplificado con el brigadismo) o como un "hipostalinismo" que se obliga a representar el conflicto existente en la sociedad (ilustrado en el "pop realista" de Francisco Brugnoli) ${ }^{70}$. Ante una breve mirada sobre la heterogeneidad de la escena plástica de fines de los sesenta y la UP, resulta evidente la insuficiencia de estos ejes "ideales" de expresión para explicar el proceso de diversificación de agencias de la "voz de la izquierda" durante el auge del ideal revolucionario. Dentro de un contexto político primero "conflictivo" (1962-1967) y luego "radicalizado" (1967-1970), es visible que la vinculación entre militancia y arte se da en diferentes niveles y esferas de implicación disciplinar y vital. Las/os artistas, involucrados en la confrontación y desborde social, otorgaron nuevos sentidos al proceso de politización del arte mismo en las instituciones, así como también refundaron desde la tarea creativa una nueva subjetividad revolucionaria y popular.

Del mismo modo, resulta evidente que la idea misma de militancia descrita en la crítica cultural de los años ochenta desconoce los distintos grados de aproximación colectiva e individual que tuvieron los artistas a la condición militante durante los años sesenta, caracterizada entonces a lo menos como dos esferas distinguibles: las actitudes intelectuales de artistas en contextos "formales" de militancia política y su despliegue "orgánico"; o aquellas independientes, aunque vinculadas a los partidos en su despliegue público, que en proximidad política adherían libremente a sus propuestas y a una izquierda "comprometida"71. De esta forma, la militancia y el compromiso representaban dos grados o anillos de implicación con los referentes políticos de la izquierda, destacando en la esfera comprometida un amplio grado de flexibilidad y discrecionalidad dentro de un horizonte de transformaciones general centrado en la acción protagónica de "la clase obrera y el pueblo organizado" "72. Esto último también signó la heterogeneidad de las intervenciones, que excedían sin duda los márgenes de la obra de arte, expresándose en prácticas que iban desde escribir un manifiesto hasta adquirir en el despliegue público cotidiano la actitud de un "trabajador de la cultura". Este es el caso de los artistas que durante la UP se plegaron a la enseñanza del arte en los balnearios populares o balpos ${ }^{73}$, el de quienes implementaron una infraestructura pública inicial relacionada a las artes visuales ${ }^{74}$, y el de quienes apoyaron el trabajo de "brocha gorda" en la elaboración del mural de la Brigada Ramona Parra en los tajamares del Mapocho

68 Carla Macchiavello, "Panamericanismo artístico como vanguardia: el rol social del arte a comienzos de los años 70", Redes intelectuales: arte y política en América Latina, Bogotá, Universidad de los Andes, 2014, p. 2.

69 Rosa Robinovich, "Las dos caras del plan cultural", 21 de febrero de 1971, Santiago de Chile. Citado de Contreras y Vassallo, op. cit., pp. 192-199.

70 Mellado, Historias de transferencia... op. cit., p. 14.

71 Tomamos referencia de esta explicación en las declaraciones que el artista chileno Guillermo Núñez realizadas en agosto de 2016 en el marco del encuentro "Conversaciones sobre el Pop en Chile", organizado por el Museo de la Solidaridad Salvador Allende, Santiago de Chile. cf. http://mssa.cl/sin-categoria/debate-y-pensamiento-conversaciones-sobre-el-pop-en-chile/ 72 Julio Pinto ed., Cuando hicimos historia: la experiencia de la Unidad Popular, Santiago, Lom Editores, 2005, p. 11.

73 Ortizpozo, "Pintura social de Chile: un capítulo inédito", El Siglo, 14 de mayo de 1972, Santiago de Chile. Citado de Gonzalo Contreras y Eduardo Vassallo, La cultura con Allende vol. 2, 1972-1973, Santiago, Alterables, 2014, p. 151.

74 Edulio Barrientos V., "UNCTAD III: Fuente inesperada de trabajo para los plásticos chilenos", El Siglo, 20 de febrero de 1972. Citado de Contreras y Vassallo, op. cit., pp. 63-66. 
que conmemoró los 50 años del Partido Comunista de Chile $(\mathrm{PCCh})^{75}$, por ofrecer algunos ejemplos más concretos. Reflejados en las palabras del escultor Carlos Ortúzar, esta condición del artista como trabajador de la cultura estaría signada durante la UP por la voluntad del creador de volverse "más necesario" para su carenciada sociedad, así como también por la capacidad del Estado en reconocer al artista como aporte en la construcción de un nuevo contexto local:

"Si Ud. hace un rápido cálculo de prioridades sociales verá que es mucho más necesario un litro de leche que una escultura de bronce. Seamos sinceros. Estoy dispuesto a cambiar de rumbo y servir al país y a la comunidad en una actividad más 'necesaria'...

Menos bla-blá con la plástica y a trabajar, pero que el trabajo sea seguro y rentado... Que el Estado abra las playas, puertos, jardines, plazas, edificios públicos, restaurantes populares, poblaciones, aeropuertos, estaciones ferroviarias, hospitales, etc. dennos también el diseño de los horribles autobuses, baldosas, dennos cosas, si hay trabajo y estamos convencidos que se los dejaremos como 'chiches' lindos, que de gusto estar enfermo, que no desmoralice estar en la 'cola' de los jubilados" 76 .

Ortúzar, que participó del alhajamiento del UNCTAD III (1972) con una obra de "arte incorporado al espacio" "77, adhería a la perspectiva que sumaba a los artistas a responsabilizarse en la ejecución de piezas que luego servirían de puertas, maceteros, asientos, pasamanos, luminarias, alineando sus inquietudes desjerarquizadamente a las problemáticas de cualquier trabajador partícipe de la construcción de un edificio. En un tono mucho menos positivo que el escultor, asumiendo la condición del artista trabajador como un "punto de llegada" y no como condición inicial, Guillermo Deisler -artista y poeta 'visivo' de Valparaíso- afirmó:

"No hay unidad popular en el área artística, porque el artista no se identifica como trabajador; la mayoría somos funcionarios públicos, lo que denota predominio del interés individual. Cumplimos muy bien como funcionarios y somos artistas en las horas libres. Por consiguiente, no somos orgánicos en el aspecto gremial, e incapaces de luchar por lugares de trabajo, posibilidades de subsistencia, materiales, medios de expresión, etc. Es urgente organizarse en base a problemas gremiales comunes y constituirse en un gremio poderoso y diligente" 78 .

La referencia más clara de esta riqueza de interpretaciones de la "misión” revolucionaria en la arena artística la podemos observar en las producciones artísticas vinculadas al propio PCCh entre 1965 y 1973. Entre las fuerzas "intitucionalistas" y "rupturistas" que se constituyeron durante el desarrollo de la vía chilena al socialismo como referentes amplios y porosos ${ }^{79}$, el PCCh como ejemplo de la primera tendencia desarrolló en el ámbito artístico una relevante tarea institucional, expresada en el impulso por parte de sus referentes y las oficinas agenciadas por éstos de un proyecto de cultura "rehabilitada" respecto de su referente previo en el "arte burgués". Este ideal lo podemos ver expresado en las opiniones que el artista y militante comunista Guillermo Núñez, quien en su calidad de director del MAC comentó sobre las piezas que conforman la colección de dicho museo "el patrimonio cultural que

75 Prensa, "Cincuenta años de historia en un mural", El Siglo, 5 de enero de 1972. Citado de Contreras y Vassallo, op. cit., pp. 20-22; Olmedo Carrasco, Carolina, "Reflexiones en torno al muralismo comunista en Chile: exposición retrospectiva de las Brigadas Ramona Parra en el Museo de Arte Contemporáneo de Santiago”, Olga Ulianova et al. eds., 1912-2012: el siglo de los comunistas chilenos, Santiago, IDEA USACH, 2012.

76 E.B.V., "Carlos Ortúzar: No creo en los supermensajes, el papel del arte es más directo y sencillo", El Siglo, 13 de febrero de 1972, Santiago de Chile. Citado de Contreras y Vassallo, op. cit., pp. 55-58.

77 Barrientos, op. cit., p. 63, 66.

78 Prensa, "Tarea de los artistas: ampliar nuestro lenguaje y transformar la realidad", El Siglo, 18 de junio de 1972, Santiago de Chile. Citado de Contreras y Vassallo, op. cit., pp. 187-188.

79 Marcelo Casals, El alba de una revolución. La izquierda y el proceso de construcción estratégica de la 'vía chilena al socialismo', 1956-1970, Santiago, Lom Ediciones, 2010, p. 10, 193-208. 
hemos heredado es horroroso" 80 " "un museo vivo, moderno, no solo debe guardar cosas. Las debe estar mostrando siempre y educando al público"s1.

Siendo uno de los partidos más numerosos en la coalición de gobierno, el PCCh fue la identidad más visible al interior del proyecto cultural de la Unidad Popular: ello gracias a su voluminoso despliegue cultural en el ámbito nacional -fortalecido por extensos y densos vínculos a nivel latinoamericano con la intelectualidad crítica, la gráfica política y el muralismo mexicano-, así como también debido a su prestigio y rol articulador de un ámbito internacional de la cultura en clave socialista y moderna, que entonces llevaba décadas de disputa ideológica y construcción en alternativa frente al régimen de sentido hegemónico del sistema-mundo capitalista ${ }^{82}$. En la época en que la oficialidad institucional del arte (el mainstream ${ }^{83}$ ) promovía al continente la pintura abstracta norteamericana como la etapa más avanzada y última del arte occidental desde la Oficina de Artes Visuales de la OEA, la matriz partidista del PCCh en la esfera internacional expandía el uso en la región del modelo de 'solidaridad': una forma de producción cultural colaborativa y no monetaria ante la necesidad de resistencia política dentro de un territorio determinado o en el exilio. Sus funciones en la arena cultural y política estaban fuertemente definidas por ciertas experiencias relativamente cercanas en el tiempo para los intelectuales chilenos, tales como la particular construcción histórica obrero-socialista chilena de inicios de siglo, la recepción material y política de la resistencia española en el exilio durante el franquismo, y el contacto con la experiencia revolucionaria mexicana y el muralismo a través de la colaboración entre ambos países a raíz del terremoto de Chillán de 1939.

A esta condición de base de sus referentes, se sumaba la vivencia contemporánea del rol condensador ejercido por Casa de las Américas en el ámbito de la cultura latinoamericana a partir de 1960, que en la urgencia de sustentar la vía revolucionaria cubana en la esfera de los intelectuales a nivel regional, imprimía al rol de la solidaridad en sus inicios un aspecto vanguardista en lo creativo que se plegaba a los términos del compromiso político ${ }^{84}$. Como abordan las correspondencias de época ${ }^{85}$ y ciertos trabajos contemporáneos en torno a la coyuntura del "Caso Padilla" 86 , esta relación armónica entre autonomía y compromiso se vería progresivamente tensionada en directa relación con el endurecimiento de las condiciones de resistencia política y económica de la isla, sin embargo hasta ese minuto constituía una prueba material e institucional de la modernidad socialista como alternativa, así como de la cultura revolucionaria latinoamericana como un conjunto de valores a exaltar vinculados a la autonomía e independencia regional. Su proyecto artístico, basado en la apropiación del proyecto moderno en clave de emergencia popular y la construcción de lazos entre las distintas luchas de los oprimidos del mundo, tendrá su cénit en el ámbito chileno en la realización de un programa de encuentro entre artistas chilenos y latinoamericanos en Cuba durante el gobierno de Salvador Allende,

80 Ernesto Saúl, "Museo Abierto", Ahora año I no. 2, 20 de abril de 1971, pp. 46-47, p. 47. Archivo Guillermo Núñez.

81 Virginia Vidal, "No solo de pan... Primer día del director del Museo de Arte Contemporáneo", El Siglo, 28 de enero de 1971. Archivo Guillermo Núñez.

82 Aquí nos apegamos a la perspectiva propuesta por el cientista social estadounidense Imannuel Wallerstein, en la que el sistema-mundo -a diferencia de la matriz teórica globalizante- permitiría la observación en la producción de un sistema único en torno a la división social del trabajo, pero que negocia, adopta y construye múltiples sistemas culturales en su arraigo específico dentro de dicha estructura. Immanuel Wallerstein, Análisis de sistemas-mundo. Una introducción, Madrid, Siglo Veintiuno Editores, 2006.

83 Camnitzer, op. cit., "Salpicón y compota".

84 Macchiavello, op. cit., pp. 9-12.

85 Un ejemplo es la correspondencia entre Haydee Santamaría, directora de Casa de las Américas, y Julio Cortázar en el marco coyuntural del "Caso Padilla", así como su respuesta a las críticas que Mario Valgas Llosa realizaba al proceso cubano por esos años. También encontramos un ejemplo local de este debate regional en los textos escritos por Enrique Lihn en Chile, en su calidad de ex-habitante de la isla. cf. Julio Cortázar, "A Haydée Santamaría. París, 4 de febrero de 1972”, Cartas 1969-1976. Edición a cargo de Autora Bernárdez y Carles Álvarez Garriga vol. 4, Buenos Aires, Penguin Random House, 2012; Haydee Santamaría, "Carta de respuesta a Mario Vargas Llosa", Revista Casa de las Américas no. 65-66, año XI [suplemento], La Habana, Casa de las Américas, 1971; Enrique Lihn, "Opinan” [Opinión del Lihn sobre el caso Padilla],. Revista Mensaje no. 20, 17 de mayo, Santiago de Chile, 1971; Antonio Avaria, "Caso Padilla". Revista Mensaje no. 20, 17 de mayo, Santiago de Chile, 1971.

86 Berríos y Jakobsen, op. cit. 
consistente en encuentros y residencias de creación/donación de obras en el Caribe y Chile (la visita de las brigadas muralistas chilenas a La Habana y el Encuentro Chile-Cuba en 1971, el Encuentro de Artistas Plásticos del Cono Sur en Santiago y el Encuentro de Plástica Latinoamericana en La Habana en 1972), así como en exhibiciones (resultantes de estos encuentros) que desde la extensión cultural de la Universidad de Chile ${ }^{87}$ enmarcaron al más importante de estos gestos político-simbólicos entre ambos referentes del socialismo latinoamericano: la visita de Fidel Castro a Chile en noviembre de 1971, y la visita de Allende a Cuba en diciembre del mismo año. Sin duda el vital debate cubano de los sesenta alimentó fuertemente la propuesta del PCCh en materia de construcción de un "arte popular", poniendo a revisión a partir de esta experiencia caribeña el sentido ideológico de la práctica artística, la posibilidad de lo "latinoamericano" como comunidad de sentido y su posibilidad de expansión en la masificación de las capitales del continente.

En el contexto institucional del arte local, la "vía" del PCCh tuvo gran protagonismo en el viraje comprometido con el horizonte revolucionario latinoamericano dado por la Facultad de Arte de la Universidad de Chile, que durante la UP oficiará como una suerte de "Ministerio de la Cultura" en términos tácticos ${ }^{88}$. A través de distintas oficinas, este contexto de formación artística atravesado por la reforma universitaria será el semillero de las iniciativas institucionales más relevantes del gobierno de Allende en materia cultural, así como también un importante combustible para sus redes internacionales en la búsqueda por romper el cerco comunicacional impuesto por los Estados Unidos en su contra. En este marco se explica el protagonismo del Instituto de Arte Latinoamericano (IAL) dirigido por el académico marxista Miguel Rojas Mix y el crítico de arte y exiliado brasileño Mario Pedrosa ${ }^{89}$, el Museo de Arte Contemporáneo dependiente de la universidad (dirigido entonces por Alberto Pérez, Guillermo Núñez y Lautaro Labbé, reconocidos militantes de izquierda). También en la posterior conformación en dicho espacio del Comite Internacional de Solidaridad Artística con Chile (CISAC), que consolidará la creación del Museo de la Solidaridad para el pueblo chileno emergido como idea durante el encuentro de contrapropaganda Operación verdad". Del mismo modo, la necesidad de construcción de una "vía cultural" en el arte para la Unidad Popular llevó a José Balmes -connotado militante del PCCh y un "modelo público" del artista comprometido- a asumir en el contexto de las campañas electorales de los sesenta la conducción primero la dirección del Departamento de Artes Plásticas (1966-1971), y luego del Decanato de dicha facultad (1972), silla que conservó hasta el golpe de Estado en septiembre de 1973. Es debido a la gran influencia y posición que artistas-militantes como el propio Balmes, Guillermo Núñez y Alberto Pérez al interior de esta facultad durante los sesenta que dicho contexto institucional posibilitó la construcción de fuertes vínculos personales a nivel local y global con una marcada tendencia de izquierda: entre ellos el propio Pedrosa de Brasil, Jorge Romero Brest y Aldo Pellegrini de Argentina, José María Moreno Galván ${ }^{91}$ de España y Giulio Carlo Argan de Italia ${ }^{92}$. Ante este nutrido contexto de debates y posiciones, ciertamente el panorama de la militancia de izquierda delineado por Richard desdibuja su relación con la historia, así como clausura prontamente una realidad que entonces se presentaba como extremadamente compleja.

87 cf. Macchiavello, op. cit., p. 9.

88 Carolina Olmedo Carrasco, "El arte y la gran política: el pensamiento crítico de José María Moreno Galván en América Latina", Práctica, estudio y crítica de la historia del arte latinoamericano: Pasado y presente, Santiago, Departamento de Historia y Teoría del Arte, Facultad de Arte de la Universidad de Chile, 2017.

89 Importante intelectual crítico brasileño, exiliado en Chile a partir de 1964 y académico de la Universidad de Chile desde entonces hasta 1973. En 1981, uno de los miembros fundadores del partido de los Trabajadores del Brasil (PTB).

90 Olmedo, op. cit.

91 Periodista de origen andaluz, militante del PCE y autor intelectual en el marco de la 'Operación Verdad' del Museo de la Solidaridad como "la primera colección a nivel mundial de arte de propiedad del pueblo". cf. Olmedo, op. cit.

$92 \mathrm{La}$ huella de estas relaciones artísticas e intelectuales podemos seguirla en el programa de exhibiciones que poblaron las salas del IAL y el MAC entre 1966 y 1973, así como en el establecimiento institucional del CISAC y las diferentes muestras que propició con las donaciones internacionales en apoyo al gobierno de Allende. Las fuentes para este seguimiento son consultables en el archivo del Museo de Arte Contemporáneo de la Universidad de Chile, cf. http://www.mac.uchile.cl/museo/conservacion 
Junto a la diversidad de aproximaciones intelectuales y creativas al problema del "arte para el pueblo", otra de las características pregnantes del arte de izquierda en los sesenta es su experiencia de la irrupción de la juventud como sujeto específico, dado en todos los aspectos de la vida pública y privada $^{93}$. La emergencia de los jóvenes como un nuevo estrato social con características y cultura propia se experimentó entonces de manera plena en distintos puntos del planeta, aparejada a la presencia de las masas en la política. Mientras la política se llenaba de referentes juveniles -las imágenes de los revolucionarios cubanos y argelinos se tornaron emblemáticas a nivel general-, la vida cotidiana sufría profundas transformaciones en las viejas formas de interacción intergeneracional. Una suerte de 'revolución cultural'94 se percibía en torno a lo juvenil como un remecimiento de toda estructura de relaciones preexistente en la modernidad occidental: la emergencia de las movilizaciones obreras, populares y estudiantiles, las luchas por la emancipación femenina, la crisis de la familia tradicional y la liberación sexual y de las identidades de género ${ }^{95}$, entre otras que entonces convocaron la acción juvenil. La emergencia de una comunidad artística en torno a la experiencia común de la universidad y el viaje formativo reforzaron la idea de una identidad juvenil abarcadora de los artistas -estudiantes, luego profesores y profesionales- durante las décadas del cincuenta y sesenta, otorgando claves de lectura en dichos términos al conflicto generacional existente en el ámbito académico. En los sesenta, la confrontación entre jóvenes y adultos en este ámbito se expresó a través de la exaltación de la identidad militante como un distintivo de "lo nuevo" frente a la caducidad aparente de todo arte/artista previo, sin implicación política directa. En dicho contexto, la proliferación de colectivos artísticos de carácter vanguardista, con un marcado interés en la apertura de las artes al espacio público y la esfera experimental (primero con Rectángulo y Signo, luego con el Grupo de Artistas Plásticos, Ancoa, Forma y Espacio, el Taller 99 y las propias brigadas muralistas, entre otros), signaban la existencia de un "universo juvenil" de la cultura de izquierdas que buscaba refundar la práctica artística y su función social en el marco de la transformación revolucionaria. La emergencia de espacios de exhibición informales y abiertos a un público general y a "otras artes" (populares, aplicadas, corporales), como la Feria de Artes Plásticas del Parque Forestal ${ }^{96}$, terminó por solidificar esta idea al punto de constituirla como un ideal modernizador de las artes.

Dentro del perfil juvenil existente, una de las figuras más relevantes será la de Alberto Pérez: artista identificado con el Partido Socialista de Chile -aunque cercano a ciertos referentes del PCCh como Balmes y Eduardo Martínez Bonati-, que en 1966 se vinculará al Ejército de Liberación Nacional (los “elenos") ${ }^{97}$, y que a partir de entonces se aproximará al discurso militante del Movimiento de Izquierda Revolucionaria (MIR), en el que permanecerá también durante la dictadura. Siendo el primer

93 Respecto de la especificidad de esta emergencia juvenil para el caso chileno, referenciamos el trabajo del historiador Patrick Barr-Melej acerca de los proyectos culturales enlazados con la emergencia juvenil en dicho país. cf. Patrick Barr-Melej, "Revolución y liberación del ser: Apuntes sobre el origen e ideología de un movimiento contracultural esotérico durante el gobierno de Salvador Allende, 1970-1973", Nuevo Mundo Mundos Nuevos, Colloques, 18 de mayo 2007, http://journals.openedition.org/nuevomundo/6057 (consultado el 3 de abril de 2018); Patrick Barr-Melej, Psychedelic Chile Youth, Counterculture, and Politics on the Road to Socialism and Dictatorship, Chapel Hill, Estados Unidos, University of North Carolina Press, 2017.

94 Eric Hobsbawm, Historia del siglo XX, Buenos Aires, Crítica, 1998, pp. 322-326.

95 Siguiendo al historiador inglés Eric Hobsbawm, "la crisis de la familia estaba vinculada a importantes cambios en las actitudes públicas acerca de la conducta sexual, la pareja y la procreación, tanto oficiales como extraoficiales, los más importantes de los cuales pueden datarse, de forma coincidente, en los años sesenta y setenta. Oficialmente esta fue una época de liberalización extraordinaria tanto para los heterosexuales (o sea, sobre todo, para las mujeres, que hasta entonces habían gozado de mucha menos libertad que los hombres) como para los homosexuales, además de para las restantes formas de disidencia en materia de cultura sexual'. Hobsbawm, op. cit., p. 324.

96 Esta feria reunía a artistas y artesanos populares, llegando a contar en sus versiones tanto con docentes-artistas de la Facultad de Arte como con intelectuales populares como Violeta Parra. cf. Jorge di Lauro y Nieves Yankovic, Los artistas plásticos de Chile, Santiago, CINEAM, 1960. Consultado en el Archivo Digital de la Cineteca Nacional, cf. http://www.ccplm.cl/sitio/los-artistas-plasticos-de-chile/ (consultado el 25 de marzo de 2018).

97 El ELN presente en Chile representó un par de apoyo del Ejército de Liberación Nacional de Bolivia formado por Ernesto "Ché" Guevara en dicho país en 1966, cuya intención principal era dar respaldo y emular a dicha guerrilla en un proceso de generación de este tipo de organizaciones a lo largo del continente, extensible de manera natural a Chile por su cercanía. 
doctor en historia del arte en Chile, la obra de Pérez desplegó durante los sesenta una actitud "latinoamericanista" y "apropiacionista" respecto de la cultura occidental, mezclando en su repertorio elementos del arte de vanguardia (el collage, la adhesión de objetos y laceracion del lienzo) con referentes provenientes de la cultura popular y de masas, entonces férreamente identificada en sus formas -el cine, la televisión y los magazines- con los jóvenes. En sus Barricada I y Barricada II (1965) observamos la mezcla de distintas materialidades y técnicas que buscan consolidar una instantánea descarnada sobre el presente, representando una interpretación libre respecto de los discursos provenientes de la militancia. La pintura industrial roja, la tela rasgada, la madera encontrada y calzada a la superficie mediante clavos, la imagen fotocopiada y emplazada en los huecos de las tablas, el título en clave confrontacional, todos estos son elementos que trasladan a los debates del arte la matanza policial acontecida en la población José María Caro en 1962, utilizando al pop como medio expresivo de la brutal violencia del cotidiano. Entre las tablas, el rostro duplicado de la actriz norteamericana Vanessa Redgrave, protagonista del film Blow Up de Michelangelo Antonioni (1966), alude igualmente a la fotografía y la sociedad masificada, impersonal e incómoda debido a la primacía de las relaciones sociales capitalistas.

Otro ejemplo de esta expresión juvenil es Poster Shop: tienda de los artistas-militantes Guillermo Núñez (PCCh) y Patricia Israel (MIR) en donde se comercializaban a bajo precio láminas impresas en color (una exquisitez en esos años), que reactualizó la herencia del cartel político a través de la incorporación de la idea de poster: referente norteamericano que, a diferencia del cartel o affiche (del francés) político, buscaba inmiscuirse en el espacio íntimo e individual del lector, convirtiéndose en una herramienta de identificación y marcaje de los espacios juveniles. Respecto de este hito de 1971, una revista local comentó:

"Los chilenos conseguimos tener nuestro afiche propio. Cuando vino la exposición De Cezanne a Miro, se vendieron reproducciones del cartel de propaganda. Los que quisieron conservarlo en buen estado no se decidieron a pegarlo con tachuelas en la pared del rincón más acogedor de la casa, sino que lo mandaron colocar en cholguán.- Asi se desato la furia por el afiche... Pero hasta ese momento nada era nacional. Ningún póster representaba nuestra realidad, nuestras costumbres, nuestra tradición. El paso lo dieron Guillermo Núñez y Patricia Israel..., en una preciosa tienda adornada con afiches de confección casera y ahora también con tarjetas de Pascua y simpáticas calcomanías que hablan de los problemas del momento: 'Ahorre agua, báñese acompañado'... Aunque el mercado es pequeño, se amplía gracias a la belleza de los afiches de la pareja de artistas y a la moda que prácticamente obliga que haya uno en cada casa" $"$.

Otros ejemplos del procesamiento de las transformaciones sociales acontecidas a partir de la emergencia de lo juvenil los podemos encontrar en las trayectorias de ciertas producciones individuales que entonces expresaron la voluntad colectiva de las mujeres por convertirse en actoras políticas de su tiempo. Este será el caso de Cecilia Vicuña, Virginia Errázuriz y Gracia Barrios quienes, cruzadas en lo íntimo por experiencias contradictorias devenidas de su condición de mujeres artistas de izquierda, pero provenientes de los sectores medios y altos, acompañarán sus hitos de vida vinculados al género -la maternidad, la dependencia, las labores domésticas- con la elaboración de piezas atípicas. Mientras Cecilia Vicuña contaba con 25 años al momento del golpe militar, expresando su obra previa la angustia juvenil e inexperta de una chilena en tránsito entre Nueva York y Santiago (Casita para pensar qué situación real me conviene a mi99, 1971), Virginia Errázuriz experimentó durante los sesenta la tensión entre su

98 Prensa, "La fiebre del póster", Eva, 27 de diciembre de 1968, Santiago de Chile. Citado en Soledad García y Daniela Berger, La Emergencia del pop: irreverencia y calle en Chile, Santiago, Museo de la Solidaridad Salvador Allende, 2016, p. 87.

99 Objeto performativo que invita a la acción e identificación del espectador respecto de ciertos referentes de su tiempo (el hippie, la guerrillera, la estrella de rock, etc.), y que lo involucra directamente en la pregunta acerca del destino de Allende y del pueblo chileno en medio de una profunda confrontación de clases en el seno de la sociedad. Esta pieza fue exhibida en 1971 en el Museo Nacional de Bellas Artes, y se ocultó familiarmente hasta 2016 en Nueva York por el temor a posibles represalias. 
carrera como artista-activista de izquierda por la UP y su realidad familiar, vinculada al latifundio y expropiada por la reforma agraria de Frei Montalva. Con la experiencia de la campaña presidencial de Allende de 1964 a cuestas, Errázuriz suspendió su obra pictórica debido a la maternidad ${ }^{100}$, elaborando una serie de textiles a partir de "desechos domésticos" que problematizaban lo político desde una perspectiva cotidiana y femenina (Mi tia languida, 1966; El Goyito, 1967) ${ }^{101}$. Por otra parte, en la trayectoria de Gracia Barrios encontraremos un ejemplo de la disparidad de síntesis entre aspectos políticos y culturales durante el gobierno de Allende, expresando la pieza textil Multitud III (1972) ${ }^{102}$ una serie de preguntas sobre el rol social del arte y el artista como un trabajador (o mejor dicho, en el ejercicio de hilván, como una trabajadora). Atendiendo al ejercicio simultáneo de transformación e institucionalización, Barrios adoptó como tema a la multitud, abordando a las marchas, concentraciones y huelgas generales ${ }^{103}$ como novedades históricas tan relevantes como la incorporación de materiales industriales y las tecnologías de reproducción de imágenes. Desde este punto de vista, el patchwork de ocho metros de largo confeccionado por Barrios ofrece la vista frontal de una marcha formada por personajes trazados a través de siluetas, obligando al espectador a tomar una posición determinada: devenir en la marcha o contra esta, sumarse al colectivo en movilización de "personas cualesquiera" campesinas, morenas, pobres del campo y la ciudad- o enfrentarse a ella como su "enemigo" dentro del paradigma de la lucha de clases. Esta visión se ve reforzada en el tratamiento del "objeto paño" como si fuera un lienzo dentro de la marcha, determinando su valoración entre un sentido entusiasta o amenazante de acuerdo a la postura ideológica portada por quien la observe. La introducción de ciertos símbolos (la bandera invertida, el amanecer) trasladan la acción narrativa desde el sujeto del arte (artista) al sujeto social (observador), propiciando su inevitable "toma de posición" frente al conflicto abierto.

\section{Ideas al cierre}

Con la victoria de Allende en 1970, muchos de los elementos potenciales en la cultura de mediados de los "largos sesenta" alcanzaron su máximo esplendor en nuestro país, aunque por la brevedad de estos procesos de apertura -menor a una década en nuestra propuesta de un ' 68 expandido' entre 1965 y 1973- no llegaron a establecer alianzas amplias y permanentes que permitieran su unicidad. En sus diferentes versiones, esta politización se encausó primero en proyectos que buscaron una radicalización de los elementos que conformaban la modernidad propuesta por la industrialización en su revisión crítica (ejemplo de ello es la amplia extensión del pensamiento dependentista en la escena cultural del Cono Sur), y que durante los sesenta expresaron las derivas propias de las formas del ocaso desarrollista y el agotamiento de la ideología como constructora de colectividades a nivel mundial. También debieron enfrentar inmediatamente después de su tiempo el auge de la crítica cultural

100 Tomamos referencia de estas experiencias personales de la artista del conversatorio realizado por Errázuriz junto a Valentina Cruz en enero de 2017 en el marco del encuentro "Conversaciones sobre el Pop en Chile", organizado por el Museo de la Solidaridad Salvador Allende, Santiago de Chile. cf. http://mssa.cl/actividad/conversatorio-actitud-poptransformaciones-artisticas-en-los-sesenta/

101 Estas obras están conformadas por sobras de casa y calle, como telas, ropas rotas, recortes de diario, palos, cartones, gráfica política en desuso, a través de los cuáles la artista cuestiona la permanencia de la obra de arte canónica, contraponiendo a los objetos recogidos frente a los "materiales nobles" como una intensificación de lo real. Las historiadoras del arte Daniela Berger y Soledad García han afirmado que estas arpilleras proponen: "un nuevo paisaje urbano provisto de información publicitaria y comercial” a partir de la referencia a corporalidades próximas y populares. cf. García y Berger, op. cit., 43.

102 A diferencia de otras obras previas de Barrios, Multitud III es una confección de paños cosidos que en su tratamiento alude a la forma rectangular del lienzo, así como a la práctica popular de coser frazadas a partir de los desechos textiles de la sociedad industrial. Esta técnica, en su condición utilitaria y decorativa, era fuertemente rescatada durante los sesenta como parte de un diálogo abierto y experimental entre las "bellas artes" y las "artes populares", buscando disolver la separación entre ambas esferas.

103 Ejemplo de estas concentraciones populares eran entonces las Huelgas generales de 1960 (50 mil personas) y la "huelga larga" de Concepción (35 mil personas). 
proveniente de las clases medias, en restringidas condiciones de debate y persecución intelectual impuestas por los regímenes autoritarios cívico-militares experimentados en gran parte de América del Sur a partir de la década del setenta.

El cierre de los procesos sociales que protagonizaron las revueltas del '68 expandido' fue una abrupta interrupción al activo escenario intelectual sudamericano, asumiendo a partir de entonces una importante desarticulación producto de las restricciones propias de sus respectivos contextos autoritarios. Si bien la riqueza de los sesenta se expresa ampliamente tras una mirada rápida a las producciones culturales revisadas en este escrito, cabe destacar que dicho ejercicio posible en la actualidad contó con un sinnúmero de dificultades para llegar a la elaboración de cualquier balance general, entre ellas la dispersión, desaparición y destrucción de fuentes y obras que enmarcó la generación de discursos en el ámbito artístico durante la dictadura en Chile. Una dificultad posterior a estas primeras, la ausencia de investigaciones historiográficas debidamente documentadas como consecuencia del difícil acceso a las fuentes, felizmente se ha superado gracias a la proliferación de distintas investigaciones e iniciativas de archivo a partir del 2000 que facilitan el acceso a fuentes documentales y artísticas del pasado reciente ${ }^{104}$.

De este modo, estimando las observaciones propuestas por la teoría crítica de esos años desde sus condiciones objetivas (determinadas por la derrota política y las estrechas condiciones de producción de sentido ofrecidas por la dictadura ${ }^{105}$ ), esperamos que este ejercicio avance en clarificar cuáles fueron las respuestas concretas que los artistas e intelectuales del arte sostuvieron durante los sesentas frente a las transformaciones sociales de su tiempo, así como poner en contexto sus aportes concretos en la esfera pública desde el lenguaje particular del arte. Acciones que, aunque críticas a los regímenes soviético y cubano, se pensaron desde la izquierda internacionalista, desde la que discutieron, reinterpretaron y desoyeron el abandono raso de la teoría marxista (impulsado a nivel internacional por el pensamiento postestructuralista en reacción al marxismo-leninismo); y también desde ahí se cuestionaron la separación entre lo político y lo intelectual que se naturalizaría como única actitud política posible durante la dictadura cívico-militar. Como veremos a continuación, esto terminó por alejar forzadamente a la izquierda partidaria de los sesenta de la cultura y de la esfera pública como ámbitos estratégicos revolucionarios, signando la pérdida de influencia y prestigio internacional de su producción cultural hacia el declive socialista de fines del siglo XX.

Para finalizar, me gustaría citar un ejemplo particular de este arte político que en los sesenta estuvo atravesado por los significados de la militancia y la juventud: El último sueño de Joe (1966), pintura del artista y escenógrafo Guillermo Núñez. Siendo uno de los principales articuladores de la cultura durante el gobierno de la UP desde la esfera comunista, Núñez es recordado como el director del MAC "de Allende" por afirmar -muy oficialistamente- su deseo de que el museo "oliera a empanada y vino tinto"106. Estuvo cerca: bajo su dirección se produjo la mítica exhibición de las Brigadas Ramona Parra y Elmo Catalán (1971) ${ }^{107}$, así como la exposición inspirada en las 40 medidas del programa de la UP, que sirvió como llamamiento a una escena artística completa en defensa de la figura de Allende ante el asedio comunicacional de los Estados Unidos. Antes de esa experiencia, Núñez había realizado una

104 Aquí destacamos particularmente la emergencia de archivos autorales como los dedicados a los artistas Guillermo Núñez (http://archivoguillermonunez.cl/) y Guillermo Deisler (http://guillermodeisler.cl/), así como también a los estudios de las historiadoras Carla Macchiavello y María Berríos que se han enfrentado con mayor amplitud al desafío de construir una visión general sobre el arte chileno en la década del sesenta. cf. María Berríos, "Struggle as Culture: The Museum of Solidarity, 19711973", Afterall no. 44 (otoño invierno), Londres; Macchiavello, op. cit.

105 Sobre las condiciones de producción cultural durante la dictadura, recomendamos la atención a los estuidos Jocelyn Muñoz, "Demoliendo el muro. Cultura televisiva / regímenes televisuales de los años ochenta en Chile", Ensayos sobre artes visuales. Prácticas y discursos de los años 70 y 80 en Chile. Volumen IV, Santiago, Lom Editores, 2015; Luis Errázuriz y Gonzalo Leiva, El golpe estético. Dictadura militar en Chile (1973-1989), Santiago, Ocho Libros, 2012; Gaspar Galaz y Milan Ivelic, Chile, arte actual, Valparaíso, Ediciones UCV, 1988; Cristi y Manzi, op. cit.

106 Saúl, op. cit., Museo abierto...

107 Olmedo, op. cit., Reflexiones... 
serie de viajes que lo formarían como artista moderno, pero que sin embargo expresaban también la novedad social portada en su propia identidad: alguno a París como becario de la educación pública ${ }^{108}$ (1953), otros al "este soviético" en actividades de su compromiso político y cultural con el teatro; el viaje a Nueva York lo realizará como "allegado" de otros artistas chilenos allí (en particular de Antúnez, nombrado agregado cultural de Chile en Estados Unidos durante el gobierno de Frei Montalva) ${ }^{109}$. Los saberes recolectados los había puesto en juego en espacios disímiles como la realización de escenografías, el diseño gráfico (trabajó como portadista de revista Ercilla), la elaboración de actividades de mediación artística y la gestión institucional. En su trayectoria de entonces resulta imposible separar sus vínculos del arte de aquellos de la política, que le permitieron entonces construir y vislumbrar alianzas en pos de la obtención de una mejor posición en el ámbito "institucional" del arte: un ámbito proclive a abrirse hacia la izquierda. Es precisamente en este último viaje en el que surge un ejemplo pertinente, cuando tras la exhibición ante un grupo de artistas neoyorkinos del documental sobre su obra dirigido por el cineasta Maurice Amar (The world of Guillermo Núnezz, 1965) ${ }^{110}$, Núñez se ve obligado a confrontar el potencial crítico en la estética irreverente del pop norteamericano frente al realismo intensificado del expresionismo informalista. Este último, entendido como "una subversión de la vida contra su cristalización" "111, era promovido en Chile por Balmes como un arte de cruda denuncia activista a la guerra de Vietnam y a las avanzadas norteamericanas en el continente: a partir de 1965, la realidad hizo más urgente el retorno a la figuración que la sustentación de cualquier "purismo" estético que alineara al creador comprometido en un estilo determinado. El último sueño de Joe es uno de los frutos de la exposición de este artista militante a la observación de estéticas hasta entonces estigmatizadas en el contexto formal de la política (donde lo norteamericano era sinónimo de imperialismo), mezclando su registro con el del prisma del internacionalismo en clave latinoamericana. Tras el golpe de 1973, que incluyó a Núñez dentro de sus listas de perseguidos y detenidos debido a su importante figuración pública, la mayor parte de sus obras pop fueron pintadas por él mismo de blanco para su protección y la de su familia. Una vez el artista en el exilio, tras ser apresado por inaugurar una exposición crítica a la dictadura en septiembre de 1975 y luego trasladado a distintos centros de exterminio y tortura (Cuatro Álamos, Villa Grimaldi, Tres Álamos, Puchuncavî), estas imágenes fueron borradas de los lienzos como de la historia a la que buscaban fortalecer, y con ellas la prueba de su aproximación subjetiva, humorística y creativa a la idea de una "plástica para la revolución". Es responsabilidad de nuestra mirada en el presente como investigadores dotar de un hilo conductor a estas piezas y reconstruir un relato que desde la parcialidad y "hacia la totalidad" se plantee su convocatoria de regreso a lo público en términos materiales y valóricos. Sólo este gesto de rescate sistemático del "espíritu de escisión" soreliano de las clases subalternas observado por Gramsci112 nos permitirá restituir en algún grado la unicidad perdida de estos trabajos ante su actual dispersión, que hoy los convierte progresivamente en meros objetos de propiedad mercantil.

108 Guillermo Núñez se educó en el Instituto Nacional (1944-1948), y luego en Arte y Teatro en la Universidad de Chile (1949-1952).

109 Isidora Neira y Natalia Castillo, "Biografía”, Archivo Guillermo Núñez, Santiago de Chile, 2017, cf. http://archivoguillermonunez.cl/biografia

110 Maurice Amar, The World of Guillermo Núñez, Nueva York, Maurice Amar, 1965, Archivo Guillermo Núñez, cf. https://youtu.be/ooYU6KJ3f0M (consultado el 15 de abril de 2018).

111 José María Moreno Galván, Autocrítica del Arte [1965], Barcelona, Barataria, 2010.

112

Antonio Gramsci, “Apuntes sobre la historia de las clases subalternas. Criterios metódicos", Cuadernos de la Carcel, C. XXIII; R. 191-193, cf. http://www.gramsci.org.ar/1931-quapos/46.htm (consultado el 15 de abril de 2018). 
Bibliografía

\section{Fuentes documentales}

Barrientos V., Edulio, "UNCTAD III: Fuente inesperada de trabajo para los plásticos chilenos", El Siglo, 20 de febrero de 1972. Gonzalo Contreras y Eduardo Vassallo, La cultura con Allende vol. 1, 1970-1971, Santiago, Alterables, 2014, pp. 63-66.

Cuevas, José Luis, "La cortina de nopal”, Ruptura s/n, México D. F., Museo Carrillo Gil, 1988, pp. 8491. Archivo ICAA MFAH.

E.B.V., "Carlos Ortúzar: No creo en los supermensajes, el papel del arte es más directo y sencillo", El Siglo, 13 de febrero de 1972, Santiago de Chile. Gonzalo Contreras y Eduardo Vassallo, La cultura con Allende vol. 2, 1972-1973, Santiago, Alterables, 2014, pp. 55-58.

Ortizpozo, "Pintura social de Chile: un capítulo inédito", El Siglo, 14 de mayo de 1972, Santiago de Chile. Gonzalo Contreras y Eduardo Vassallo, La cultura con Allende vol. 2, 1972-1973, Santiago, Alterables, 2014, p. 151.

Prensa, "La fiebre del póster", Eva, 27 de diciembre de 1968, Santiago de Chile.

Prensa, "Cincuenta años de historia en un mural", El Siglo, 5 de enero de 1972. Gonzalo Contreras y Eduardo Vassallo, La cultura con Allende vol. 2, 1972-1973, Santiago, Alterables, 2014, pp. 20-22.

Prensa, "Tarea de los artistas: ampliar nuestro lenguaje y transformar la realidad", El Siglo, 18 de junio de 1972, Santiago de Chile. Gonzalo Contreras y Eduardo Vassallo, La cultura con Allende vol. 2, 1972 1973, Santiago, Alterables, 2014, pp. 187-188.

Robinovich, Rosa, "Las dos caras del plan cultural", 21 de febrero de 1971, Santiago de Chile. Gonzalo Contreras y Eduardo Vassallo, La cultura con Allende vol. 1, 1970-1971, Santiago, Alterables, 2014, pp. 192-199.

Saúl, Ernesto, "Museo Abierto", Ahora año I no. 2, 20 de abril de 1971, pp. 46-47. Archivo Guillermo Núñez.

Vidal, Virginia, "No solo de pan... Primer día del director del Museo de Arte Contemporáneo", El Siglo, 28 de enero de 1971. Archivo Guillermo Núñez.

\section{Fuentes impresas}

Aguiló, Osvaldo, Plástica neovanguardista, antecedentes y contextos, Santiago de Chile, CENECA, 1983.

Brunner, José Joaquín, "Campo artístico, escena de 'avanzada' y autoritarismo en Chile", Arte en Chile desde 1973. Escena de Avanzada y Sociedad. Documento FLACSO no. 46, Santiago de Chile, FLACSO, 1987.

Camnitzer, Luis, Didáctica de la liberación: arte contemporáneo latinoamericano, Montevideo, Centro Cultural de España, 2007.

Casals, Marcelo Middle Class and Dictatorship in Chile: Consent, Negotiation, and Crisis, 1970-1983, tesis de la Universidad de Wisconsin-Madison para obtención del grado de Doctor en Historia de América Latina y el Caribe, expuesta en las XXII Jornadas de Historia de Chile, Universidad Austral, Valdivia, noviembre de 2017.

El alba de una revolución. La izquierda y el proceso de construcción estratégica de la 'vía chilena al socialismo', 1956-1970, Santiago, Lom Ediciones, 2010.

De Juan, Adelaida, "Actitudes y reacciones" [1974], Damian Bayón ed., América Latina en sus artes, México D. F., UNESCO / Siglo XXI Editores, 1983, pp. 34-44.

Faletto, Enzo, "Chile 1950-1973: transformaciones y conflictos", Chile 100 años de artes visuales: segundo periodo, 1950-1973, entre modernidad y utopía, Santiago, Museo Nacional de Bellas Artes, 2000, pp. 51-67.

Fox, Claire F., Arte panamericano: políticas culturales y guerra fría, Santiago de Chile, Metales Pesados, 2016. 
Freire, Cristina "Apuntes sobre el arte subterráneo en Latinoamérica, 1960-70", Sistemas, Acciones y Procesos 1965-1975 (ed. Rodrigo Alonso), Buenos Aires, Fundación Proa, 2011, pp. 42-47.

Galaz, Gaspar y Milan Ivelic, Chile, arte actual, Valparaíso, Ediciones de la Universidad de Valparaíso, 1988.

García, Soledad y Daniela Berger, La Emergencia del pop: irreverencia y calle en Chile, Santiago, Museo de la Solidaridad Salvador Allende, 2016.

Guilbaut, Serge, "Éxito: de cómo Nueva York les robó a los parisinos la idea de modernismo, 1948”, Alonso, Rodrigo ed., Imán: Nueva York: Arte argentino de los años 60, Buenos Aires, Fundación PROA, 2010, pp. 37-65.

Hadjinikolaou, Nicos, Historia del arte y lucha de clases, Buenos Aires, Siglo Veintiuno Editores, 2005.

Hobsbawm, Eric, Historia del siglo XX, Buenos Aires, Crítica, 1998.

Longoni, Ana, Vanguardia y Revolución. Arte e izquierdas en la Argentina de los sesenta-setenta, Buenos Aires, Ariel, 2014.

Macchiavello, Carla, "Panamericanismo artístico como vanguardia: el rol social del arte a comienzos de los años 70", Redes intelectuales: arte y politica en América Latina, Bogotá, Universidad de los Andes, 2014.

Mellado, Justo Pastor, "Historias de transferencia y densidad en el campo plástico chileno (19732000)", Chile 100 años de artes visuales: tercer periodo, 1973-2000, transferencia y densidad, Santiago, Museo Nacional de Bellas Artes, 2000, pp. 8-23.

Moreno Galván, José María, Autocrítica del Arte [1965], Barcelona, Barataria, 2010.

Muñiz-Huberman, Angelina, El canto del peregrino. Hacia una poética del exilio, Barcelona, Gexel / Universidad Autónoma de Barcelona, 1999.

Olmedo Carrasco, Carolina, "Reflexiones en torno al muralismo comunista en Chile: exposición retrospectiva de las Brigadas Ramona Parra en el Museo de Arte Contemporáneo de Santiago", Olga Ulianova et al. eds., 1912-2012: el siglo de los comunistas chilenos, Santiago, IDEA USACH, 2012.

"El arte y la gran política: el pensamiento crítico de José María Moreno Galván en América Latina", Práctica, estudio y crítica de la historia del arte latinoamericano: Pasado y presente, Santiago, Departamento de Historia y Teoría del Arte, Facultad de Arte de la Universidad de Chile, 2017.

Oyarzún, Pablo, "Crítica; historia", "Campo artístico, escena de 'avanzada' y autoritarismo en Chile", Arte en Chile desde 1973. Escena de Avanzada y Sociedad. Documento FLACSO no. 46, Santiago de Chile, FLACSO, 1987.

Pinto, Julio ed., Cuando hicimos historia: la experiencia de la Unidad Popular, Santiago, Lom Editores, 2005.

Richard, Nelly, Cuerpo correccional, Santiago de Chile, Francisco Zegers Editor, 1980.

, Márgenes e instituciones: arte en Chile desde 1973 [1983], Santiago de Chile, Metales Pesados, 2007.

Richard, Nelly, Claudia Zaldívar y Pablo Oyarzún eds., Arte y política, Santiago de Chile, Universidad ARCIS, 2005.

Saúl, Ernesto, Pintura social en Chile. Nosotros los chilenos no. 13, Santiago, Empresa Editora Nacional Quimantú, 1972.

Thielemann, Luis, "El Movimiento Popular y la historiografía en Chile: Elementos para un balance a 40 años del Golpe de Estado", Revista de Historia y Geografía no. 29, 2013, pp. 105-130.

Varas, Paulina, "De la circulación artística chilena a la circulación de la Escena de Avazada", ICAA Documents Project Working Papers no. 1, septiembre de 2007.

Venegas Espinoza, Fernando, Violeta Parra en Concepción y la frontera del Biobio, 1957-1960: recopilación, difusión del folklore y desborde creativo, Concepción, UDEC / CNCA, 2017.

\section{Fuentes digitales}

Acuña, Constanza, Origen y devenir del Museo de Arte Popular Americano Tomás Lago, Santiago, MAPA, s/f, cf. http://www.mapa.uchile.cl/proyectos/index.php (consultado el 25 de marzo de 2018). 
Amar, Maurice, The World of Guillermo Núñez, Nueva York, M. Amar, 1965, Archivo Guillermo Núñez, cf. https://youtu.be/ooYU6KJ3f0M (consultado 15 de abril de 2018).

Berríos, María y Jakob Jakobsen, The Revolution must be a school of unfettered thought, exposición en la 31a Bienal de Sao Paulo, 2014, cf. http://www.31bienal.org.br/en/post/1501 (consultado el 25 de marzo de 2018).

Bowen, Martín, "El proyecto sociocultural de la izquierda chilena durante la Unidad Popular. Crítica, verdad e inmunología política", Nuevo Mundo Mundos Nuevos, 21 de enero 2008, cf. http://journals.openedition.org/nuevomundo/13732 (consultado el 25 de marzo de 2018).

Consejo de Monumentos Nacionales de Chile, Mural Quinchamali de Nemesio Antúnez. (1958), Santiago, CMN, 2011, cf. http://www.monumentos.cl/monumentos/monumentos-historicos/muralquinchamali-nemesio-antunez (consultado el 25 de marzo de 2018).

Di Lauro, Jorge y Nieves Yankovic, Los artistas plásticos de Chile, Santiago, CINEAM, 1960. Archivo Digital de la Cineteca Nacional, cf. http://www.ccplm.cl/sitio/los-artistas-plasticos-de-chile/ (consultado el 25 de marzo de 2018).

Flores del Pino, Carlos, Descomedidos y chascones, Santiago, Departamento de Cine, Universidad de Chile, 1973. Cineteca Virtual Universidad de Chile, cf.

http://www.cinetecavirtual.cl/fichapelicula.php?cod=34 (consultado 15 de abril 2018).

Gramsci, Antonio, “Apuntes sobre la historia de las clases subalternas. Criterios metódicos”, Cuadernos de la Carcel, C. XXIII; R. 191-193, cf. http://www.gramsci.org.ar/1931-quapos/46.htm (consultado el 15 de abril de 2018).

Neira, Isidora y Natalia Castillo, "Biografía", Archivo Guillermo Núnẽz, Santiago de Chile, 2017, cf. http://archivoguillermonunez.cl/biografia

Richard, Nelly, Lo politico en el arte: arte, politica e instituciones", E-misferica no. 6.2, Nueva York, Hemispheric Institute / NYU, 2009, http://hemisphericinstitute.org/hemi/es/e-misferica62/richard (consultado el 25 de marzo de 2018).

, "Todo comenzó asî", Punto de fuga s/n, Santiago, Estudiantes de Historia y Teoría del Arte, Universidad de Chile, 2015, http://www.revistapuntodefuga.com/?p=1872

Samaniego, Fernando, “Alain Touraine: los movimientos sociales se desvinculan de la política”, El País, domingo 14 de abril de 1974, Madrid, http://elpais.com/diario/1978/04/14/sociedad/261352807 850215.html (consultado el 25 de marzo de 2018). 